Çukurova Üniversitesi Eğitim Fakültesi Dergisi

Vol: 50 Numb: 2 Page: 1437-1463

https://dergipark.org.tr/tr/pub/cuefd

\title{
The Effect of Changes in the Transition to Secondary Education Systems on Mathematics Achievement \\ Bekir S. GÜR ${ }^{a}$ (ORCID ID - 0000-0001-8397-5652) \\ Ahmet ÖZTÜRK ${ }^{b}$ (ORCID ID - 0000-0002-2683-5415) \\ Mahmut ÖZER C (ORCID ID - 0000-0001-8722-8670) \\ H. Eren SUNA ${ }^{d 2^{*}}$ (ORCID ID -0000-0002-6874-7472)
}

${ }^{a}$ Ankara Yıldırım Beyazıt Üniversitesi, İnsan ve Toplum Bilimleri Fakültesi, Ankara/Türkiye

${ }^{\mathrm{b}}$ SESRIC, Ankara/Türkiye

c Millî Eğitim Bakanlığı, Ankara/Türkiye

${ }^{d}$ Millî Eğitim Bakanlığı, Ankara/Türkiye

\begin{tabular}{l} 
Article Info \\
\hline DOI: $10.14812 /$ cufej.887197 \\
\hline Article history: \\
Received $\quad 26.02 .21$ \\
Revised $\quad 01.09 .21$ \\
Accepted $\quad 22.10 .21$ \\
\hline Keywords: \\
Transition Systems, \\
SBS, \\
TEOG, \\
LGS, \\
Mathematical Achievement.
\end{tabular}

\begin{abstract}
Turkey has witnessed numerous changes in the transition to secondary education systems in the 2000s. The Secondary Education Institutions Examination (OKS), the Level Specifying Examination (SBS), and the Transition from Primary to Secondary Education System (TEOG) were implemented between 2010 and 2018. Lastly, in 2018, the Transition to High School System (LGS) has been adopted as a new system. This study examines the effect of the changes in secondary education transition systems between 2010 and 2019 on students' mathematics achievement in $9^{\text {th }}$ grade. The data of all students who were in $9^{\text {th }}$ grade between 2010 and 2019 were analyzed through multiple linear regression methods. The parents' education level, $8^{\text {th }}$ grade mathematics achievement, age, and gender are considered as external variables and their effects are controlled statistically. The findings revealed that a significant and sharp decrease in $9^{\text {th }}$ grade mathematics achievement occurs after every system-level change in the transition systems. Additionally, the largest decrease in mathematics achievement is found in TEOG. Based on the results, it is recommended to make incremental improvements instead of radical changes to alleviate the problems in secondary education transition systems.
\end{abstract}

\begin{tabular}{l} 
Ortaöğretime G \\
\hline Makale Bilgisi \\
\hline DOI: $10.14812 /$ cufej.887197 \\
\hline Makale Geçmişi: \\
Geliş $\quad 26.02 .21$ \\
Düzeltme $\quad 01.09 .21$ \\
Kabul $\quad 22.10 .21$ \\
\hline Anahtar Kelimeler: \\
Ortaöğretime Geçiş Sistemi, \\
SBS, \\
TEOG, \\
LGS, \\
Matematik Başarısı. \\
\end{tabular}

\section{Başarısına Etkisi}

\section{Öz}

Türkiye'de 2000'li yıllar sonrasında ortaöğretime geçiş sistemlerinde önemli değişiklikler yapılmıştır. Ortaöğretim Kurumları Sınavı'ndan (OKS) Seviye Belirleme Sınavları'na (SBS'ler) geçiş yapılmış, sonrasında Temel Eğitimden Ortaöğretime Geçiş (TEOG) sistemine geçilmiştir. 2018 yılında TEOG sistemi kaldırılmış ve yeni bir sistem olarak Liseye Geçiş Sistemi (LGS)'ne geçilmiş olup 2021 yılı itibarıyla halen LGS sistemi yürürlüktedir. Bu çalışmada 2010-2019 yılları arasında ortaöğretime geçiş sistemlerinde yapılan değişikliklerin öğrencilerin ortaöğretimin ilk yılındaki, yani dokuzuncu sınıf matematik başarıları üzerindeki etkileri incelenmiştir. Araştırmada, 2010-2019 yılları arasında ilköğretimden ortaöğretime geçiş yapan tüm öğrencilerin verileri kullanılmış ve veriler çoklu doğrusal regresyon analiziyle çözümlenmiştir. Yıllar arasında yapılan karşılaştırmalarda anne ve baba eğitim düzeyi, sekizinci sınıf matematik başarısı, yaş ve cinsiyet değişkenlerinin etkisi kontrol edilmiştir. Çalışmada elde edilen bulgular, ortaöğretime geçiş sistemindeki her sistem değişimi sonrasında dokuzuncu sınıf matematik başarılarında keskin düşüşlerin gerçekleştiğini göstermektedir. Her üç sistem içerisinde en büyük düşüşün TEOG'a geçiş sonrasında gerçekleştiği görülmektedir. Çalışmada elde edilen bulgular ışığında, ortaöğretime 


\section{Introduction}

Education has various social roles beyond providing students with cognitive and affective skills. There is a general consensus that the improvement of education systems contributes to the countries' socioeconomic development and alleviating the inequality (Corrales, 1999). Accordingly, many countries have made educational changes and reforms at different scales. Policy change refers to minor changes or new policies in the existing education system. Policy reform, on the other hand, indicates comprehensive and fundamental policy changes (Cerna, 2017). Change in education policy is a complex process involving diverse segments of society (Viennet \& Pont, 2017). Moreover, it is difficult to establish links between the targeted policies and outcomes because of the fact that education is multilayered, and it requires a much longer time to achieve the goals (Wurzburg, 2010). Changes or reforms in education policies can often be inconclusive based on the fact that goals may not be clear and realistic, the results may occur in a long time, the relevant stakeholders do not participate in the processes, and the relevant actors, especially the teachers, are frequently resilient to change (Corrales, 1999). Consequently, comprehensive education reforms often do not lead to solid and intended changes even if they are implemented (Cerna, 2017; Fullan, 2000). The simultaneous implementation of multiple regulations is another problem, because it leads to additional difficulties in determining the unique impact of each regulation.

Although the claims of radical reformists in education are attractive, almost all of the reformists, who promised that they would change the education system radically, softened their claims after a while or stopped making their claims (Tyack \& Cuban, 1997). The main reason is that making radical changes is challenging especially in public schools. American education historians David Tyack and Larry Cuban named this phenomenon as "the grammar of schooling". Every language may include new words or phrases over time, but the grammar changes barely over time. Historically, most efforts to reform the grammar of the school (e.g., age-based classrooms, credits/diploma, rule-defined bureaucracy, decadesold traditional pedagogy) have failed to some extent (Tyack \& Cuban, 1997). Although numerous attempts have failed, many countries frequently discuss comprehensive reforms. For example, the results of the Programme for International Student Assessment (PISA) of the Organization for Economic Cooperation and Development (OECD) in the early 2000s, were considered as indicators that the education system in many countries was in crisis and comprehensive reforms were needed (Wurzburg, 2010). In other words, PISA has had an external effect for education reform in many countries, especially in Germany. However, this effect occurred on a diverse scale in different states and countries such as Germany (Waldow, 2009).

The success and failure of the educational reform efforts in various countries has prompted international organizations and researchers to investigate the factors behind the results of education reforms. For example, in 2008 the Education Policy Committee of OECD discussed why some reforms were successful and how to persuade the public to support them. An important result from these studies is that specific studies and empirical research at the country level are critical to understand the success or failure of education policies (Cerna, 2017; Wurzburg, 2010). An interesting example is the Czech Republic which spent 14 years creating consensus on developing, testing and revising the content of school-leaving examinations (Viennet \& Pont, 2017).

The main motive for frequent changes in education systems is the expectation that changes or reforms will lead to remarkable solutions to existing problems (Cuban, 2008). The major rationale and the decision makers' intention towards reforms in Turkey is the magnitude of high expectations. To illustrate, there has been an overemphasis on both the changes in curriculum and the large-scale assessment systems in Turkey. While numerous changes and attempts were made, such as curriculum revisions (Gür, 2014; Gür \& Çelik, 2009), initiating the Movement of Enhancing Opportunities and 
GÜR, ÖZTÜRK, ÖZER \& SUNA - Çukurova Üniversitesi Eğitim Fakültesi Dergisi, 50(2), 2021, 1437-1463

Improving Technology (FATiH) Project (Akcaoglu, Gumus, Bellibas, \& Boyer, 2015), preparing foreign language-based classrooms at the fifth grade (Gür et al., 2016), the expectations towards the results of the changes were overwhelming. Moreover, these changes were expected to provide quick and solid solutions to the existing problems.

Radical policy changes are frequently made in the Turkish education system (Alpaydın, 2018; Aydın Baş \& Şentürk, 2017; Konan et al., 2019). The official reports and strategy documents also affirm that too frequent and sudden changes are made in the education system. For example, the Ministry of National Education's 2010-2014 Strategic Plan, "short-term education plans" and "frequent changes" were considered as development areas (MEB, 2009, p. 59). Similarly, in the 10th Development Plan, one of the issues that negatively affect the quality of the Turkish education system is highlighted as "frequent changes in the educational policies". (Ministry of Development, 2014, p. 27).

Based on an examination of the strategy plans prepared in different years, it is reasonable to say that while there is a complaint about frequent and sudden changes in the education system, the expectation towards policy changes is still alive. The dilemma here is that the discourse of complaining that changes are made too often in the education system coexists with the discourse that it is necessary to make changes or reforms in the education system due to the existing needs. The legitimacy of frequent changes is based on the perception that there is a demand for change in society. In 2018, "the public perception towards the need for a change in the education system" was mentioned as an opportunity in the Ministry of National Education's 2019-2023 Strategy Plan (MEB, 2019a, p. 33). It is understandable, then, that this demand for change becomes continuous in areas such as education where change constantly occurs. It becomes critical to set measurable targets for these high demands and to monitor and evaluate the short- and long-term results of these targets holistically. Otherwise, it would not be possible to determine the difference between the practices that are valuable and those that do not lead toward the targets. On the other hand, the high frequency of the changes and the practitioners' lack of proper knowledge about the recent changes can create a resistance to change or cause a loss of motivation (Akman \& Hacıfazlığlu, 2019; Gürses \& Helvacı, 2011).

The comprehensive changes in the examination systems take the first place among the reforms in the education system in Turkey (Alpaydın, 2018; Dinç et al., 2014; Gür \& Çelik, 2009). These changes are implemented to the education system in a relatively short time due to the centralized structure of the Turkish education system (OECD, 2018; World Bank, 2005) compared to other OECD countries. The major aim of these changes is to take a step towards the improvement of the education system. However, related research shows that students, parents and administrators complain and are negatively affected by the comprehensive changes made in both the university entrance system and the transition system to secondary education, (Demirbilek \& Levent, 2019; Dinç et al., 2014; Zayimoğlu Öztürk, 2014). Since the past, it has been seen that in the discussions and practices regarding the education system in Turkey, a great deal of value has been attributed to the changes in examination systems (Gür \& Çelik, 2009). Despite the ascribed importance, there is a lack of comprehensive and multidimensional empirical research on the impact of policy changes on student achievement.

Although the aims of the changes in the transition system to secondary education in Turkey are to alleviate the dependency on out-of-school resources, to better identify students' competencies, to minimize test anxiety, and to increase the quality of education, studies showed that these goals are achieved only partially (Atılgan, 2018; Buluç et al., 2014; Gür \& Çelik, 2009; Zayimoğlu Öztürk, 2014). For example, a study from MoNE shows that nearly half of the students needed academic support in private teaching institutions for the Placement Exam (SBS), and the preparation for the exam increased the test anxiety of students and parents (Education Research and Development Department, 2010). On the other hand, there was not a remarkable decrease in the number of students taking the exam during this period, on the contrary, it increased with the next system-Transition from Primary to Secondary Education System (TEOG). With the Transition to High School System (LGS) after TEOG, the rate of 
students placed in secondary education institutions based on the central examination score decreased significantly.

Some of the changes in the transition system to secondary education create particular negativities that were not predicted at the beginning. For example, placing students in secondary education institutions based on the central examination scores has increased the hierarchical structure in the secondary education system (Çelik, 2015). In addition, the placement of all students in high schools according to academic performance, leads to significant differences in the curriculum applied in schools, increased disciplinary problems in schools where low-achieving students are concentrated, and the increased achievement gap between schools (Bölükbaş and Gür, 2020). It is known that there is a significant relationship between students' socioeconomic status and the achievement gap between schools (OECD, 2019a; Özer, 2020b). Recent studies on the transition to secondary education system in Turkey revealed that the placing of students in high schools based on their achievement stratifies students in high schools according to their socioeconomic status (Bölükbaş and Gür, 2020; Karaağaç Cingöz and Gür, 2020; Suna et al., 2020a; 2020b). Therefore, the severity of the problems varies between high school types. As a result, the transition systems to secondary education play an important role in the achievement gap between schools or inequalities in education.

The achievement gap and the hierarchy between high schools in Turkey stand out as the most fundamental problem of secondary education (Gür et al., 2013). In international monitoring studies, a high achievement gap between high schools is emphasized in Turkey (World Bank, 2013; OECD, 2010; Suna, Tanberkan, \& Özer, 2020). The main reason for the increase in the achievement gap between schools, which emerge and cannot be compensated sufficiently in primary education, is the homogeneous clustering of students in high school types according to their academic achievement (Özer, 2020a). The grouping of students into school types by their academic achievement is described as school tracking, and it has been shown in studies that tracking increases inequalities in education (Hanushek \& Woessmann, 2006; Özer \& Perc, 2020).

These studies show that radical changes may lead to unpredictable effects on the system. In this context, different studies to be carried out to determine these effects will contribute to the adequate determination of the positive and negative outcomes of these changes. Therefore, this study aims to determine the effect of comprehensive/systemic changes in secondary education transition systems in Turkey on mathematical achievement. In this context, the effect of the changes in the transition systems to secondary education between 2010-2019 on the mathematical achievement of the students in the first year of secondary education (ninth grade) were examined. The ninth grade is selected based on the fact that it is the first grade in which the students' academic performance after the transition system is measured. Academic achievement in the ninth grade was taken into account, since the first results reflecting the possible impact of the transition system emerged at this grade level. Additionally, mathematical achievement is selected based on that it is one of the competency areas in national and international large-scale monitoring studies and variance of mathematics is mostly higher than other achievement criteria. The present study has unique characteristics in terms of the data set, method and scope it uses. First, the student population data who transitioned from primary to secondary education between 2010-2019 were used in the study. Secondly, the effect of changes in the transition system to secondary education on students' achievement has been empirically revealed in Turkey. Thus, the paper examined this possible effect for the first time by considering the mathematical achievement of 9th grade students. Additionally, diverse characteristics including age, gender, parental education level, and students' eighth grade mathematical achievement were statistically controlled. The study also presents suggestions for education policies in Turkey based on the results of the empirical research. Based on the main aim of the research, answers to the following research questions were sought:

Did students' mathematics achievement change significantly after the changes in the transition systems? 
GÜR, ÖZTÜRK, ÖZER \& SUNA - Çukurova Üniversitesi Eğitim Fakültesi Dergisi, 50(2), 2021, 1437-1463

- Did students' mathematics achievement change significantly after the changes in the transition systems when students' gender, age, parent education level and eighth grade achievements are controlled?

\section{Changes in Secondary Education Transition Systems in Turkey}

In Turkey, frequent changes are made in transitions between education levels. The main reason behind these changes is the criticism that central exams negatively affect the diverse aspects of the education system (eg. central examinations increase students' stress, anxiety, and their orientation towards private lessons and courses, etc.) (Çelik, 2012). Therefore, the fact that examination systems are considered as the major problem in the education system leads to the assumption that the improvements in these systems will also lead to an increase in the quality of the education system. With these changes, it was aimed to minimize the students' dependency on out-of-school resources and private teaching institutions, to assess students' achievement and competencies in a comprehensive way, to reduce test anxiety and to increase the quality of education (Gür \& Çelik, 2009).

During the 2000s, regulations such as Secondary Education Institutions Exam (OKS), Level Specifying Exam (SBS), SBS, TEOG and finally LGS systems were implemented in Turkey (Table 1). Although central exams continue to be the main determinant in the transition to secondary education in different years, it is seen that there are constant changes in the name of the exams, their content, the method of implementation, and the score calculation (Alpaydın, 2018; Biçer, 2014; Çelik, 2012; Gür et al. ., 2013). With the LGS, which has been implemented since 2018 , approximately $10 \%$ of the students have been placed to secondary education institutions based on their central exam scores, and the other students (nearly $90 \%$ of students) are placed to secondary education institutions based on their area of residence and their school achievement.

Table 1.

Changes in Transition Systems to Secondary Education (2000-2020).

\begin{tabular}{cl}
\hline System & Period of Implementation \\
\hline OKS & $\begin{array}{l}\text { Started in } 2004 \\
\text { Last implementation in } 2007\end{array}$ \\
\hline SBS Tests & In 2008, implemented at 6. and 7. grades \\
& In 2009, implemented at 6., 7. and 8. grades \\
& In 2010, implemented at 7. and 8. grades \\
\hline SBS & In 2011, implemented at 8. grades \\
& In 2012, implemented at 8. grades \\
\hline TEOG & Implemented between 2013 and 2016 \\
\hline LGS & Started in 2017, implemented at 8.grades \\
& Continues in 2020 \\
\hline
\end{tabular}

Table 2 shows the number of students who took the central exam and placed in secondary education institutions by year. Based on data on Table 2, the LGS has the lowest rate of students who are placed to secondary education institutions based on their central examination scores. 
Table 2.

Number of Exam Takers and Number of Students Placed to Secondary Education Institutions

\begin{tabular}{|c|c|c|c|c|c|}
\hline $\begin{array}{l}\text { Academic } \\
\text { Year }\end{array}$ & $\begin{array}{l}\text { Transition } \\
\text { System }\end{array}$ & $\begin{array}{l}\text { Number of } \\
\text { 8th Grade } \\
\text { Graduates }\end{array}$ & $\begin{array}{r}\text { Number of } \\
\text { Graduates } \\
\text { Choose Among } \\
\text { Secondary } \\
\text { Education } \\
\text { Institutions }\end{array}$ & $\begin{array}{r}\text { Number of } \\
\text { Graduates } \\
\text { Placed to } \\
\text { Secondary } \\
\text { Education } \\
\text { Institutions }\end{array}$ & $\begin{array}{r}\text { Rate of Graduates } \\
\text { Placed to } \\
\text { Secondary } \\
\text { Education } \\
\text { Institutions by } \\
\text { Central Test Scores }\end{array}$ \\
\hline 2010-2011 & SBS & 1.228 .634 & 668.117 & 366.762 & 29,85 \\
\hline 2011-2012 & SBS & 1.254 .660 & 777.096 & 315.770 & 25,17 \\
\hline $2012-2013$ & SBS & 1.240 .556 & 904.114 & 626.207 & 50,48 \\
\hline 2013-2014 & TEOG & 1.257 .324 & 1.136 .546 & 1.057.799 & 84,13 \\
\hline 2014-2015 & TEOG & 1.256 .306 & 1.108 .182 & 1.036 .809 & 82,53 \\
\hline $2015-2016$ & TEOG & 1.147 .179 & 1.001 .975 & 956.190 & 83,35 \\
\hline 2016-2017 & TEOG & 1.167 .536 & 1.019 .577 & 935.241 & 80,10 \\
\hline 2017-2018 & LGS & 1.155 .294 & 437.070 & 127.283 & 11,02 \\
\hline 2018-2019 & LGS & 1.187 .260 & 439.419 & 138.993 & 11,71 \\
\hline $2019-2020$ & LGS & 1.670 .258 & 568.627 & 206.619 & 12,37 \\
\hline
\end{tabular}

\section{Method}

\section{Research Model}

This study aims to determine the effect of the changes in the high school transition systems on students' mathematics achievement in the last ten years. The study was designed as a causal comparison research and these studies examine the possible causes or consequences of emerging or previously occurring situations (Creswell, 2014; Salkind, 2010). Unlike experimental studies, the independent variable cannot be manipulated by the researchers and there is no possibility of experimental control since the effect under question mostly occurs in the past. Since the impact cannot be tested experimentally in causal comparison studies, other factors that may have an effect on the dependent variable should be taken into account when interpreting the results (Salkind, 2010). The changes in the transition systems, which is the independent variable of present research, cannot be manipulated by the researchers. The effects of external variables including age, gender, earlier achievement and parents' education level that may affect students' ninth grade mathematics achievement were controlled statistically.

\section{Population}

In the present study, population data of the students' attending the 9th grade in the last ten years in Turkey were used. The research data consists of a total of 12 million 230 thousand 358 students who 
GÜR, ÖZTÜRK, ÖZER \& SUNA - Çukurova Üniversitesi Eğitim Fakültesi Dergisi, 50(2), 2021, 1437-1463

were in the 9th grade between 2010-2011 and 2019-2020 academic years. The number and gender distribution of these students by years are given in Figure 1.

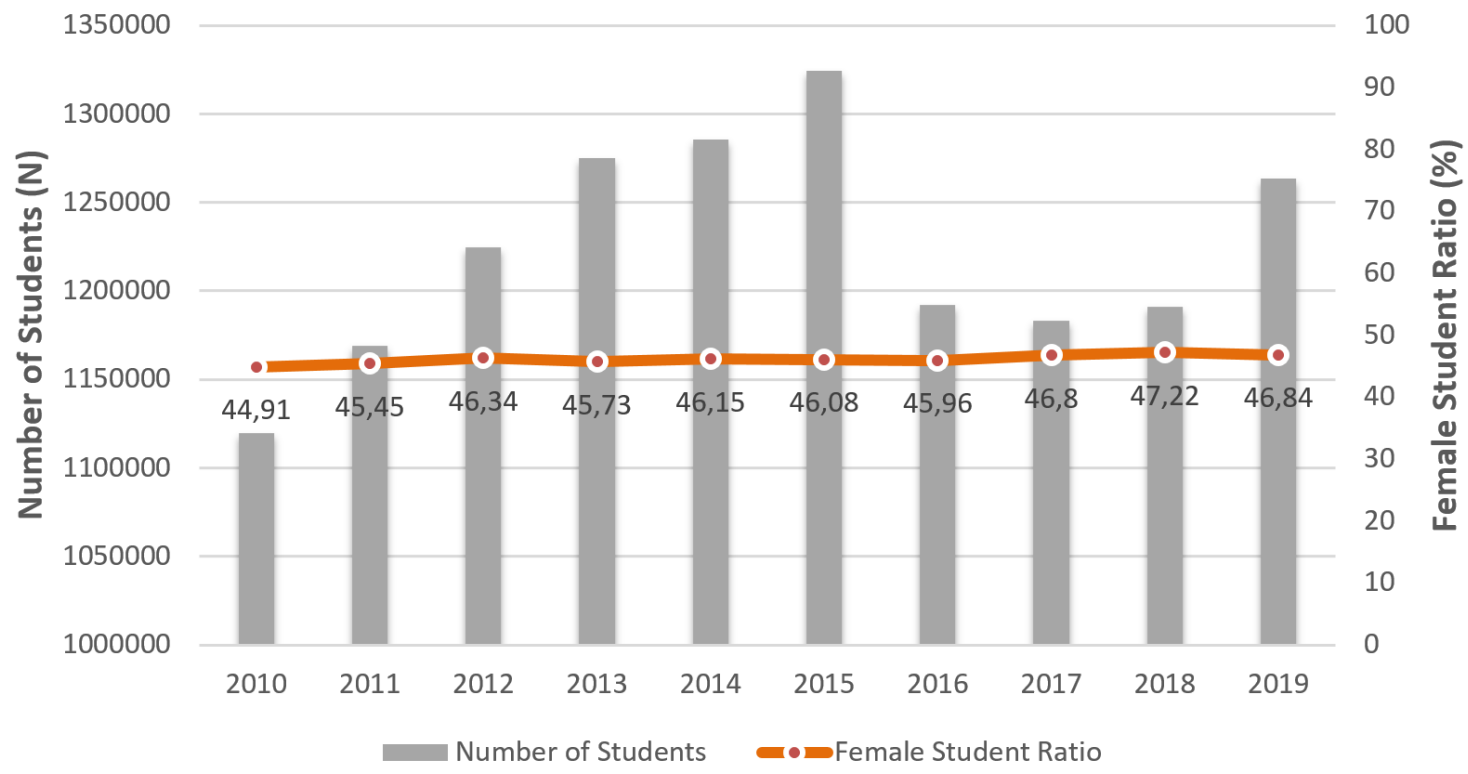

Figure 1. Distribution of Students in the Research Population by Years and Female Student Ratio

As seen in Figure 1, the number of students in the population varies between 1.119 .894 and 1.324 .604 over the academic years. The gender distribution of students was mostly balanced and showed partial changes over the years.

\section{Data Analysis}

Within the scope of the research, the mathematical school test scores were taken into account as an indicator of the academic achievement of the students between the years of 2010-2011 and 2019-2020. Due to the structure of the transition system, in the eighth-grade scores, the mean score of the first and third tests were considered since the second tests are implemented centrally in some academic years. However, in the ninth grade scores, the obligatory first and second tests are considered because the third tests were not implemented in some years. Since the students' mathematical achievement scores varied between 0 and 100 in all years, no standardization was applied to them. In this way, a simple interpretation of the change in the mean scores in different years was provided.

In the study, a two-step process was followed to examine the change in mathematical achievement of eighth and ninth-grade students over the years. In the first step, the change in the mathematical achievement of the ninth grade students in the eighth and ninth grades analyzed descriptively over the years. This stage is important in that it shows the change in mathematical achievement in the last ten years without controlling any variables.

In the second stage, the change of mathematical achievement of 9th grade students in consecutive years was examined by controlling the external variables. This method ensures that the possible effects of various familial and personal variables that were not covered in the research is eliminated. This is critical because causal comparison studies have two main limitations: the lack of experimental control and the inability to manipulate the independent variable (Creswell, 2014). Statistical control methods offer opportunities to compensate for the lack of experimental control. In this manner, the students' personal and demographic data in the e-school system were checked and the available variables shown 
GÜR, ÖZTÜRK, ÖZER \& SUNA - Çukurova Üniversitesi Eğitim Fakültesi Dergisi, 50(2), 2021, 1437-1463

in various studies to have significant effects on academic achievement (MEB, 2018, 2019b, 2020; OECD, 2019b; Pellizzari \& Billari, 2011) were used for control purposes. These variables are earlier achievement, age, gender and parental education level. The multiple linear regression model, which includes all of the variables whose effects were controlled, is given below:

$$
y i j=\propto+j d i j+X i \Pi+i
$$

In this model, yij is student's 9th grade math test score in the $\mathrm{j}$ academic year, dij is a dummy variable and takes the value 1 if the student $i$ is in the 9th grade in the $j$ academic year, $X i$ is other personal control variables, and $i$ is the error term. Personal control variables are student's 8 th grade math test scores, age, gender, and the average years of schooling, which corresponds to the level of school completed by the parent with the highest education level, representing the education of the parents. Thus, the $\mathrm{j}$ coefficient provides the change in students' 9th grade mathematics achievement value compared to the previous year after controlling the effect of other variables.

At this stage, nine regression models were tested using the (1) model to calculate the change in students' mathematics achievement in the last ten years compared to the previous year, by eliminating the effect of external variables. For example, in the regression model that predicts the mean score change in 2011 compared to 2010, the dummy variable takes the value of 1 for the students in the 9th grade in the 2011 academic year, and 0 for the students in the 9th grade in the 2010 academic year. If the value representing 2011 is significant, the mean in this year is significantly different from the mean in 2010.

In the analyses, the academic year was referred to as the starting year of the school. For example, the 2010 academic year refers to the 2010-2011 academic year. It was necessary to restructure the parent education level variable because only the level of school completed by the parents is included in the e-school dataset. In the prediction of the mean education year; illiterate 0 , literate and primary school students 2 years, primary school graduates 5 years, secondary school graduates 8 years, high school graduates 11 years, associate degree graduates 13 years, 3-year education institute graduates 14 years, undergraduate graduates 15 years, master degree graduates are accepted as 17 years and doctorate graduates as 20 years. Similar approaches were also used in the studies of Aydemir and Kırdar (2017) and Öztürk and Tümen (2018).

The prediction approach used in regression models is the least squares method. Since the error terms of the students in the same school may be related to each other, the error terms were clustered at the school level in all regression estimates. Working with student population data causes the data volume to be very large and even the smallest differences to be statistically significant. Therefore, the significance of the differences between the mean scores in the evaluation of the first research question was not tested.

There is missing data in the variables controlled in the second step, and only the data of the students with all required data registered to the e-school system were considered. Since this situation caused a partial decrease in the student population, the significance of the coefficients calculated in the regression analysis was taken into account. Research data has been used with the official permission (65968543/622.01-E.16394512) of the Ministry of National Education, Information Technologies Department.

\section{Findings}

While examining the effects of changes in secondary education examination systems on the mathematics achievement of 9th grade students, a descriptive comparison was made without any statistical control in the first step. In order to examine the effect of transition systems, the mathematical 
achievement averages of the students enrolled in the 9th grade in the last ten years were considered with the mean achievement of these students in the eighth grade, and the findings are given in Figure 2.

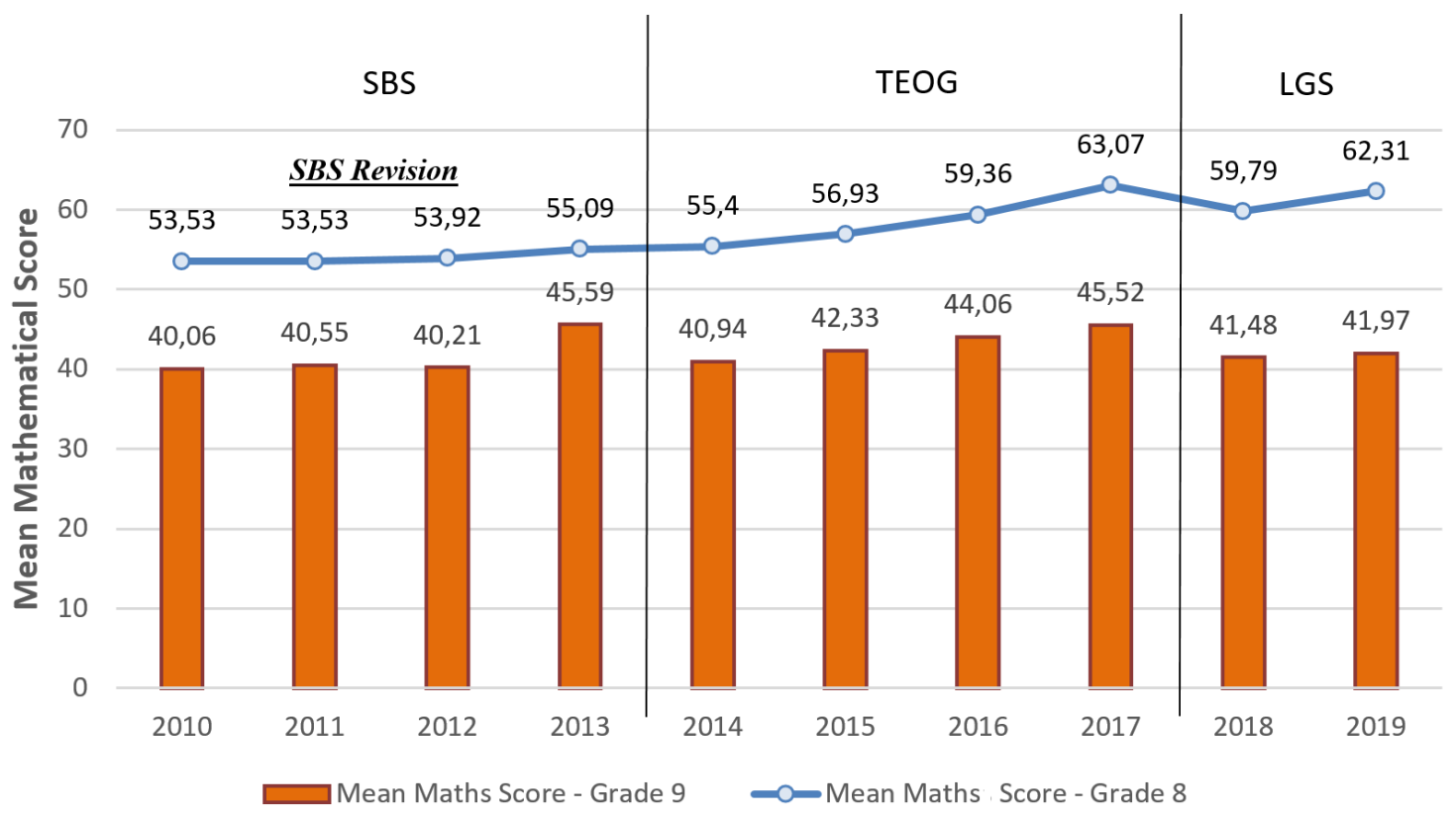

Figure 2. Changes in Students' 8th and 9th Grade Mathematics Grades Over the Years

Figure 2 shows that the mathematical achievement of the 9th grade students in the last ten years fluctuates significantly just after the changes in the transition systems. In the transition to TEOG that took place between 2013 and 2014, the mean score of ninth grade students decreased by approximately 4.55 points (10\%). Similarly, in the transition to LGS between 2017 and 2018, the mean mathematical achievement decreased by 4.04 points (8.88\%). On the other hand, the change observed in the revision of the SBS between 2011 and 2012 is extremely limited (0.34 points, below 1\%). Another important finding in the 9th grade mean scores is that the mathematical achievement tends to increase over the years in all three transition systems. Therefore, the effect caused by the change in the transition system seems to lead to a decrease in mathematical achievement, but the mean achievement increased again over time.

When the eighth-grade mathematics achievements of ninth grade students are examined in Figure 2, it is possible to collect the eighth grade mean scores in three groups. In the first group between the years 2010 and 2013, the mean scores are quite close and increased partially in 2013. In the second group between 2014 and 2017, mean scores increase continuously and at higher rates, comparatively. In the third group between 2018 and 2019, the mean average decreases partially and then raises again.

Based on the three groups, the first result is that the second group, in which the scores increased substantially, occurred in the years when TEOG was applied. In this context, TEOG has been the only system in which the scores have increased at greater rates and continuously after a remarkable decrease. When the percentage of difference between the lowest and highest mean scores in transition systems is considered, it is seen that the difference is $2.91 \%$ in SBS, $13.84 \%$ in TEOG and $4.21 \%$ in LGS. Therefore, TEOG has been the transition system with the highest score increase in the system. The fact that the school achievement is determinant in the placement with TEOG may be a major reason for this 
GÜR, ÖZTÜRK, ÖZER \& SUNA - Çukurova Üniversitesi Eğitim Fakültesi Dergisi, 50(2), 2021, 1437-1463

increase. The second prominent result is that the scores always tend to increase after years of change in all three transition systems.

The first findings indicate that the score change patterns after the transitions show a general similarity at both grade levels. As it is seen in Figure 2, the mean scores of the 9th grade students and the 8th grade mean scores of these students change with a similar trend after the changes in transition systems. However, the changes in 9th grade achievement more clearly indicate the shocks regarding the changes in the transition systems.

In the second step of the study, the effect of external variables was controlled, and focused on how the change in transition systems related with achievement. The regression coefficients and the variation of beta coefficients is given in Table 3 and Figure 3.

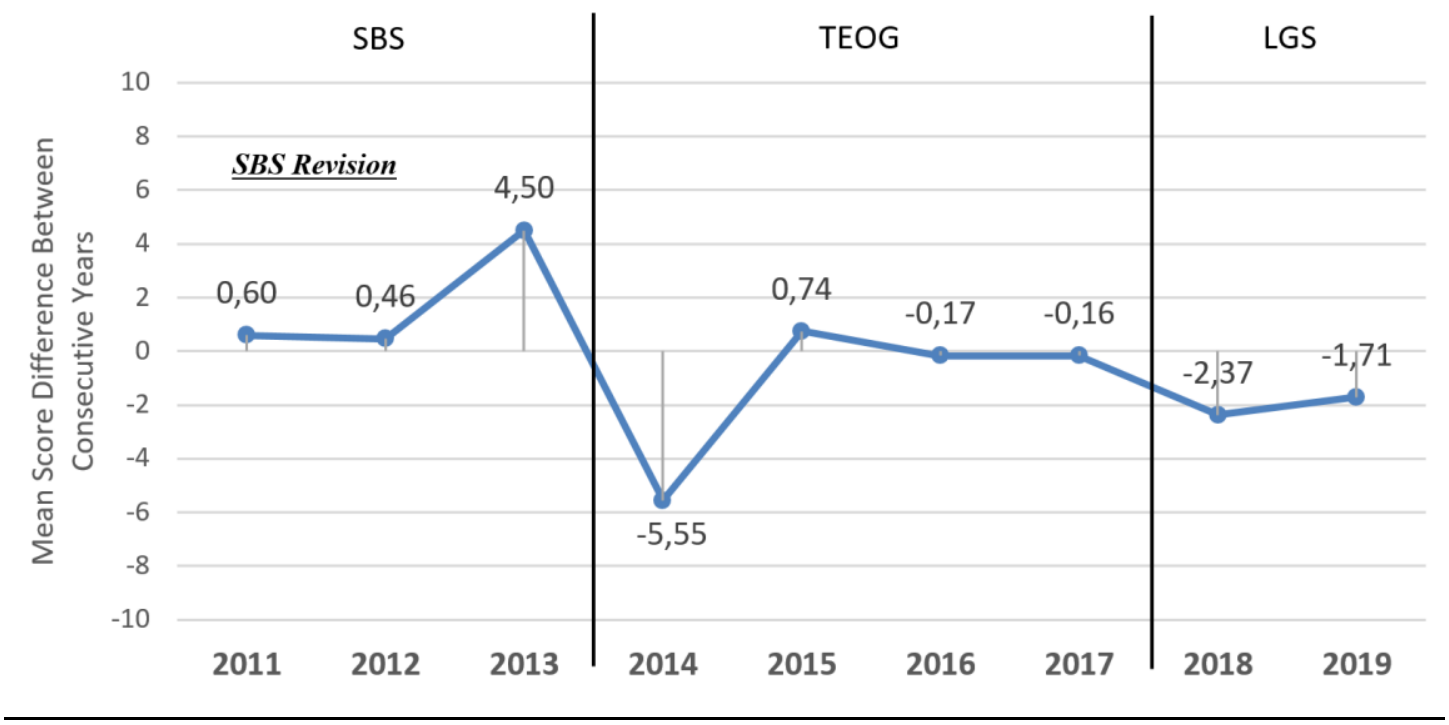

Figure 3. Changes in Students' 9th Grade Mathematics Grades Over the Years

Table 3.

Regression Results in Consecutive Years *,*

\begin{tabular}{|c|c|c|c|c|c|c|c|c|c|}
\hline & $\begin{array}{l}2011- \\
2010\end{array}$ & $\begin{array}{l}2012- \\
2011\end{array}$ & $\begin{array}{l}2013- \\
2012\end{array}$ & $\begin{array}{l}2014- \\
2013\end{array}$ & $\begin{array}{c}2015- \\
2014\end{array}$ & $\begin{array}{l}2016- \\
2015\end{array}$ & $\begin{array}{l}2017- \\
2016\end{array}$ & $\begin{array}{l}2018- \\
2017\end{array}$ & $\begin{array}{l}2019- \\
2018\end{array}$ \\
\hline Constant & 25,29 & 25,10 & 26,93 & 30,67 & 22,68 & 21,48 & 18,63 & 9,17 & $-5,16$ \\
\hline Beta & $0,60^{*}$ & $0,46^{*}$ & $4,50 *$ & $-5,55^{*}$ & $0,74^{*}$ & $-0,17$ & $-0,16$ & $-2,37^{*}$ & $-1,71 *$ \\
\hline Math. Achievement - 8th Grade** & $0,56^{*}$ & $0,56^{*}$ & $0,51^{*}$ & $0,50^{*}$ & $0,52 *$ & $0,52 *$ & $0,53^{*}$ & $0,59 *$ & $0,58^{*}$ \\
\hline Gender** & $2,94 *$ & $3,15^{*}$ & $2,57 *$ & $2,00 *$ & $2,02 *$ & $2,05^{*}$ & $2,25 *$ & $1,79 *$ & $1,86^{*}$ \\
\hline$A g e^{* *}$ & $-1,24^{*}$ & $-1,19 *$ & $-1,09 *$ & $-0,94 *$ & $-0,88^{*}$ & $-0,77^{*}$ & $-0,60 *$ & $-0,21 *$ & $0,54 *$ \\
\hline Parental Education** & $0,21 *$ & $0,24 *$ & $0,20 *$ & $0,15^{*}$ & $0,22 *$ & $0,23 *$ & $0,19 *$ & $0,25^{*}$ & $0,48^{*}$ \\
\hline
\end{tabular}

${ }^{*} p<0,01,{ }^{* *}$ Control Variables 
As seen in Figure 3 and Table 3, when the personal and family variables of the students are controlled, students' mathematical scores decrease significantly in the years of system changes. Especially in the year of 2013, as a result of the placement of all students in schools according to TEOG scores, there was a sharp decrease in 9th grade achievement $(6=-5.55, p<0.01)$. In 2018, as a result of the transition to the LGS system, there was a decrease in mean scores again. However, the severity of the decrease in the transition to LGS was lower than that of TEOG $(B=-2.37, p<0.01)$. Basically, in the years when fundamental changes in the examination systems (TEOG and LGS), a significant decrease occurs in mean student achievement, while statistically insignificant or minor changes were found in the years 2014, 2015 and 2016, when the system was not changed.

On the other hand, it is seen that the revision of the SBS from 2011 to 2012 did not have a negative effect on the students' 9 th grade achievement, and even the average increased significantly $(B=0.46$, $p<0.01$ ). Moreover, in 2013, when there was no change in the examination systems, the mean score of the 9th graders increased significantly compared to 2012.

When the findings are evaluated holistically, it seems that the changes in the transition systems have a significant negative effect on the mathematical achievement. As seen in the first step of the study, system changes may have secondary/additional effects on 8th grade scores in addition to 9th grade achievement. It also is found that the mean scores of 9th graders tend to increase in years without system changes or with limited changes.

\section{Discussion \& Conclusion}

Transition systems between school levels are used for a long while for the placement of students in secondary education and higher education institutions in Turkey. Especially after the 2000s, the transition systems to secondary education have significant structural differences. Although it is important to examine the results of these changes, the empirical studies on this subject are limited (Küçüker, 2017; Suna et al., 2020a; TED, 2010). Studies on transition systems mostly aim to determine the variables related to the test performance (Akay, 2017; Anasız, Ekinci, \& Anasız, 2018; Aslan, 2017; Karaağaç Cingöz \& Gür, 2020). In these studies, it is shown that test performance is related to various characteristics such as students' socioeconomic status, enrollment in preschool education, reading habits and school characteristics. Other studies focus on the opinions of students, teachers, and school administrators on transition systems between (Baş \& Kıvılcım, 2019; Karakaya, Bulut \& Yılmaz, 2020; Özkan, Karataş, 2016; Şahin et al., 2012). It is seen that the transition systems are determinant on the behaviors and attitudes of the students, so the changes between these systems may also lead to differences on behaviors and attitudes. Therefore, changes in transition systems potentially have an impact on students' achievement with their structural characteristics.

In this study, the effects of the changes in the transition systems to secondary education on student achievement were examined through the students' mathematical achievement in the first year of high school. Findings show that sharp decreases occurred in the ninth-grade mathematical achievements immediately after the years when radical changes were made in the transition system to secondary education. These decreases are consistently obtained both in two cases: the direct comparison of mean scores and the comparison of mean scores when controlling for students' age, gender, previous academic achievement and parental education level. The consistent decline in students' mathematical achievement immediately after the changes made in the transition systems indicates that system changes are associated with achievement. Indeed, after TEOG was implemented in 2013 and LGS was implemented in 2017, students' mean scores decreased significantly. However, the decrease in LGS is lower than TEOG. On the other hand, findings revealed that there was a positive change in student achievement in the years without extensive changes and in the years with minor changes. The findings of the study indicate that limited interventions may be better than radical changes in the transition system to secondary education for the student achievement. 
GÜR, ÖZTÜRK, ÖZER \& SUNA - Çukurova Üniversitesi Eğitim Fakültesi Dergisi, 50(2), 2021, 1437-1463

Although the focus of the study was to determine the effects of high school transition systems on student achievement, it was also possible to compare the effect of extending the duration of compulsory education from 8 to 12 years, as the " $4+4+4$ system" introduced in 2012 . The results show that this remarkable extension did not lead to a decrease in student achievement. In other words, the changes in transition systems seem to be more determinant than other systemic changes.

The fluctuation in student achievement led by changes in transition systems is critical in terms of revealing the effect of these systems on education. The findings show that major changes in the transition system, regardless of its structure and regulations, lead to a significant and negative change in student achievement. As shown in studies before, the regulations in the transition systems negatively affect the students, parents and administrators (Demirbilek \& Levent, 2019; Dinç et al., 2014; Zayimoğlu Öztürk, 2014). For the first time, the present study showed that major changes in the system negatively affect student achievement. Immediately after all the comprehensive changes in the transition systems, a decrease in the students' achievement occurs, and then the achievement tends to increase again until another systematic change. This result shows that the system reacts immediately to the structural changes in the transition system, then this negative effect can be compensated over time.

While reform efforts at the diverse levels of the education system are becoming critical in many countries (Fullan, 2009), it seems more reasonable to focus on improvements (Wurzburg, 2010) rather than system-level and comprehensive reforms (Wurzburg, 2010). In other words, it is argued that smaller-scaled revisions and improvements lead to more positive results in comparison with comprehensive reforms in the education system (Corrales, 1999). In this context, it is recommended to improve the education system with minor interventions rather than reforming it fundamentally. 


\section{Türkçe Sürümü}

\section{Giriş}

Eğitim, öğrencilere bilişsel ve duyuşsal becerilerin kazandırılmasının ötesinde birçok toplumsal işleve sahiptir. Eğitim sistemlerinin geliştirilmesinin ve güçlendirilmesinin ülkelerin sosyoekonomik kalkınmasına ve eşitsizliğin azalmasına katkısı olduğu yönünde genel bir uzlaşı vardır (Corrales, 1999). Bundan dolayı, tüm ülkelerde eğitim politikalarında değişik ölçeklerde ve hızlarda değişimler ve reformlar yapılmaktadır. Politika değişikliği, mevcut yapıda küçük değişikliklere veya yeni politikalara işaret etmektedir. Politika reformu ise, daha kapsamlı ve köklü politika değişikliklerine işaret etmektedir (Cerna, 2017). Eğitim politikalarında değişikliğe gitmek, toplumun farklı kesimlerini kapsayan ve oldukça karmaşık bir süreçtir (Viennet ve Pont, 2017). Dahası, diğer alanlara kıyasla eğitim alanı genellikle büyük ve çok katmanlı olmasının yanında hedeflenen amaçlara ulaşmak için çok daha uzun bir süre gerektirdiği için, hedeflenen politikalarla sonuçlar arasında ilişki kurmak oldukça güçtür (Wurzburg, 2010). Yapılmak istenen hedeflerin net ve gerçekçi olmaması, çıktıların uzun sürelerde elde edilebilmesi, ilgili tarafların süreçlere katılmaması ve başta öğretmenler olmak üzere ilgili aktörlerin değişikliği benimsememesi gibi nedenlerle eğitim politikalarında değişiklik veya reform adımları çoğunlukla sonuçsuz kalabilmektedir (Corrales, 1999). Dolayısıyla, planlı bir şekilde eğitimde değişiklik yapma amacını taşıyan kapsamlı eğitim reformları, uygulamaya konsa bile çoğu zaman bir değişikliğe yol açmayabilmekte veyahut kurumsallaşamamaktadır (Cerna, 2017; Fullan, 2000). Eğitimdeki politika değişiklikleri ve reformları ile ilgili diğer bir sorun da genellikle birden çok düzenlemenin eşzamanlı uygulanması nedeniyle her bir düzenlemenin özgün etkisinin belirlenmesinde yaşanan zorluktur.

Eğitime ilişkin köklü reformlar yapma fikri cazip görünse de yapılan reformlarla eğitim sistemini kökten değişime uğratacağını vadeden reformistlerin hemen tamamı bir süre sonra bu iddialarını yumuşatmış veya iddialarından tamamen vazgeçmiştir (Tyack ve Cuban, 1997). Bunun temel nedeni, özellikle kamu okullarında köklü değişim yapmanın kolay olmamasıdır. Amerikalı eğitim tarihçileri David Tyack ve Larry Cuban'ın kavramsallaştırmasıyla söylersek, kamu okullarının kendine has bir grameri (the "grammar" of schooling) vardır. Tıpkı gerçek dillerdeki gibi, her dilde zamanla kimi yeni kelimeler veya kalıplara yer açılmaktadır ancak gramer zamanla çok az değişime uğramaktadır. Tarihsel olarak, okulun gramerini (ör. yaş temelli sınıf düzeni, krediler/diploma, kurallarla tanımlanmış bürokrasi, geleneksel olarak onlarca yıldır devam eden pedagoji) reform etmeye yönelik çabaların hemen hemen tamamı başarısızlıkla sonuçlanmıştır (Tyack ve Cuban, 1997). Sayısız reform girişimi başarısız olmasına rağmen, birçok ülke zaman zaman kapsamlı reformları tartışmaktadır. Sözgelimi, 2000'li yılların başında Ekonomik Kalkınma ve İş Birliği Örgütü’nün (OECD) Uluslararası Öğrenci Başarısını Değerlendirme Araştırması (PISA) çalışması sonucunda, birçok ülkede eğitim sisteminin bir krizde olduğu ve dolayısıyla reform yapılması gerektiği tartışılmıştır (Wurzburg, 2010). Bir başka ifadeyle, PISA başta Almanya olmak üzere birçok ülkede eğitim reformu yapılması için dışsal bir şok etkisi yapmıştır. Ancak bu şok etkisi farklı ülkelerde ve Almanya gibi federal hükümetle yönetilen ülkelerde farklı eyaletlerde farklı şekillerde yansımıştır (Waldow, 2009).

Muhtelif ülkelerdeki eğitim reformu çalışmalarının kimilerinin başarılı kimilerinin ise başarısız olması, başta uluslararası kuruluşları ve konuyla ilgili araştırmacıları, eğitim reformunun başarısının belirleyicileri üzerine çalışmaya itmiştir. Sözgelimi, 2008 yılında OECD Eğitim Politikası Komitesi bir toplantı yaparak bazı reformların neden başarılı olduğunu ve reformları desteklemesi için kamuoyunun nasıl ikna edilebileceğini tartışmıştır. Bu çalışmalardan çıkan önemli bir ders, eğitim politikalarının başarı ya da başarısızlığını anlamak için ülke düzeyinde spesifik çalışmaların ve ampirik araştırmaların oldukça önemli olduğudur (Cerna, 2017; Wurzburg, 2010). Bu konuda ilginç bir örnek, lise bitirme sınavlarının içeriğini oluşturma, test etme ve yeniden düzenleme konusunda uzlaşı oluşturmak için 14 yıl harcayan Çekya'dır (Viennet ve Pont, 2017). 
Eğitim sistemlerinde sık değişiklik yapılmasının başıca nedenlerinden biri, değişikliklerin veya reformların büyük çözümlere yol açacağı yönündeki beklentilerdir (Cuban, 2008). Türkiye'de de kapsamlı reform taleplerinin ve dolayısıyla karar alıcıların bir şekilde reforma girişmelerinin temel nedeni, bu beklentilerin büyüklüğüdür. Gerçekten de geçmişten beri Türkiye'de eğitim sistemine ilişkin tartışmalarda ve uygulamalarda, gerek eğitim programı değişikliklerine gerekse de sınav sistemlerindeki değişikliklere gereğinden fazla değer atfedildiği görülmektedir. Yeni bir müfredata geçilmesi (Gür, 2014; Gür ve Çelik, 2009), Fırsatları Artırma ve Teknolojiyi İyileştirme Hareketi (FATiH) Projesinin başlatılması (Akcaoglu, Gümüş, Bellibas ve Boyer, 2015) beşinci sınıfın yabancı dil ağılıklı bir sınıf olarak düzenlenmesi (Gür vd., 2016) gibi birçok değişikliğe gidilirken değişikliklerin sonuçlarına ilişkin aşırı beklentiler oluşmuştur. Yapılan değişikliklerde genellikle o günün sorunlarına hızlı cevaplar sunabileceği beklenen uygulamalar dikkate alınmıştır.

Türkiye'de eğitim politikalarında sıklıkla köklü politika değişikliklerine gidildiği bilinmektedir (Alpaydın, 2018; Aydın Baş ve Şentürk, 2017; Konan vd., 2019). Türkiye'deki resmî rapor ve strateji belgelerinde de eğitim sisteminde sık değişiklikler yapıldığına ilişkin tespitler mevcuttur. Örneğin, Millî Eğitim Bakanlığı tarafından hazırlanan Millî Eğitim Bakanlığı 2010-2014 Stratejik Planı'nda "eğitim planlamalarııı kısa dönemli yapılması" ve "sık sık değişiklikler yapılması" zayıf yön olarak gösterilmiştir (Milli Eğitim Bakanlığı-MEB, 2009, s. 59). Benzer şekilde, muhtelif resmi ve sivil paydaşların görüşlerini de dikkate alarak Kalkınma Bakanlığı tarafından 10. Kalkınma Planı hazırlık çalışmaları kapsamında yayınlanan Eğitim Kalitesinin Artırılması Özel ihtisas Komisyonu raporuna göre, Türkiye'de eğitim sisteminin kalitesini olumsuz etkileyen hususlardan birisi "uygulanan politikaların sık değişmesi" olarak ifade edilmiştir (Kalkınma Bakanlığı, 2014, s. 27).

Farklı yıllarda hazırlanan strateji planlarından hareketle şunu söylemek mümkündür: Her ne kadar eğitim sisteminde sık değişiklik olduğuna ilişkin bir şikâyet olsa da eğitim sisteminin değişime veya reforma ihtiyacı olduğuna ilişkin beklenti de canlı olarak varlığııı sürdürmektedir. Burada ortaya çıkan ikilem, bir yandan eğitim sisteminde çok sık değişiklik yapıldı̆̆ına ilişkin şikâyet söyleminin, dünyada yaşanan hızlı değişimden dolayı eğitim sisteminde de değişim veya reform yapmak gerektiğine ilişkin bir söylem ile aynı anda varlığını sürdürmesidir. Bu durumda da yapılan sık değişimlerin meşruiyeti toplumdaki değişime yönelik talep ile ilişkilendirilmektedir. 2018 yılında hazırlanan Millî Eğitim Bakanlı̆̆ı 2019-2023 Strateji Planı'nda da "kamuoyunda eğitim sisteminde değişiklik yapılması gerektiğine ilişkin algı" bir firsat olarak zikredilmiştir (MEB, 2019a, s. 33). Eğitim gibi değişimin sürekli devam ettiği alanlarda bu değişim talebinin sürekli olması beklendik bir durumdur. Önemli olan, bu beklentiye yönelik ölçülebilir hedefler koymak, bu hedeflerin kısa ve uzun vadeli sonuçlarını bütünsel olarak değerlendirebilmektir. Aksi durumda, sürekli güncellenen uygulamalar arasında gerçekten yararlı olanlar ile istenen yararı sağlayamayanlar arasındaki farkı anlamak mümkün olmayacaktır. Diğer taraftan, değişimlerin çok kısa süreli olması ve değişimler hakkında uygulayıcıların bilgi eksikliği eğitim paydaşlarında değişime karşı direnç oluşturabilmekte veya motivasyon kaybına yol açabilmektedir (Akman ve Hacıfazlıŏlu, 2019; Gürses ve Helvacı, 2011).

Türkiye'de eğitim sisteminde yapılan reformlar içerisinde, sınav sistemlerine yönelik yapılan kapsamlı değişiklikler ilk sırada yer almaktadır (Alpaydın, 2018; Dinç vd., 2014; Gür ve Çelik, 2009). Yapılan bu değişimler diğer OECD ülkelerine kıyasla Türkiye'de eğitim sisteminin merkeziyetçi yapısı (OECD, 2018; World Bank, 2005) nedeniyle kısa bir süre içerisinde tüm eğitim sistemine uygulanabilmiştir. Bu değişimlerdeki amaç, kuşkusuz, eğitim sisteminin iyileştirilmesine yönelik bir adım atılması isteğidir. Bununla birlikte gerek üniversite giriş sisteminde gerekse de ortaöğretime geçiş sisteminde yapılan kapsamlı değişikliklerle birlikte öğrencilerin, velilerin ve yöneticilerin şikayetçi oldukları ve olumsuz etkilendikleri gösterilmiştir (Demirbilek ve Levent, 2019; Dinç vd., 2014; Zayimoğlu Öztürk, 2014). Geçmişten beri Türkiye'de eğitim sistemine ilişkin tartışmalarda ve uygulamalarda, sınav sistemlerine dolayısıyla sınav sistemlerinde yapılan herhangi bir değişikliğe çok büyük anlamlar yüklendiği görülmektedir (Gür ve Çelik, 2009). Ancak, atfedilen öneme rağmen yapılan değişikliklerin öğrenci başarısı üzerine etkisine dair kapsamlı ve çok-boyutlu ampirik araştırma eksikliği görülmektedir. 
Türkiye'de liselere geçiş sistemlerindeki değişikliklerde okul dışı kaynaklara ve dershaneye olan bağımlıı̆̆ azaltmak, okulu merkeze almak, öğrenci yetenek ve yeterliliklerini daha iyi tespit etmek, sınav stresini azaltmak, eğitim kalitesini artırmak gibi amaçlar güdülmüş olsa da söz konusu değişikliklerin hedeflerini gerçekleştirme düzeylerinin düşük olduğu görülmektedir (Atılgan, 2018; Buluç vd., 2014; Gür ve Çelik, 2009; Zayimoğlu Öztürk, 2014). Örneğin, MEB tarafından yayımlanan bir araştırmaya göre, öğrencilerin yarııına yakını Seviye Belirleme Sınavı (SBS) için dershaneye gitmeye devam etmiş ve sınava hazırlık sürecinin öğrenci ile velilerde stres ve kaygı düzeyini artırdığı görülmüştür (Eğitimi Araştırma ve Geliştirme Dairesi Başkanlı̆̆ı, 2010). Diğer taraftan, bu dönemde sınava giren öğrenci sayısında ciddi bir azalma yaşanmadığı gibi, daha sonra getirilen TEOG ile birlikte tam tersine artmıştır. TEOG'dan sonra getirilen LGS ile birlikte, merkezi sınav puanı ile tercih yaparak bir ortaöğretim kurumuna yerleşen öğrenci oranı önemli miktarda azalmıştır.

Liselere geçiş sistemi değişikliklerinde hedefe ne kadar ulaşıldığının ötesinde başlangıçta öngörülmeyen kimi olumsuzlukları da beraberinde getirdiği görülmektedir. Örneğin, öğrencilerin merkezi bir sınavda aldıkları puanlar üzerinden liselere yerleştirilmeleri ortaöğretim sistemindeki hiyerarşik yapıyı artırmıştır (Çelik, 2015). Ayrıca, tüm öğrencilerin puanlarına göre liselere yerleştirilmesi sonucu, okullarda uygulanan eğitim programında fiili farklılaşmalar yaşanmış, düşük başarılı öğrencilerin yerleştirildiği okullarda disiplin sorunları artmış ve genel olarak okullar arasındaki başarı farkları artmıştır (Bölükbaş ve Gür, 2020). Öğrencilerin sosyoekonomik seviyeleri ile okullar arası başarı farklarııın oluşması arasında önemli bir ilişkinin olduğu bilinmektedir (OECD, 2019a; Özer, 2020b). Türkiye'de son yıllarda ortaöğretime geçiş sistemi üzerine yapılan bazı çalışmalar, öğrencilerin başarılarına göre liselerde ayrıştıııması uygulamasının öğrencileri sosyoekonomik düzeylerine göre liselerde tabakalandırdığını ortaya koymuştur (Bölükbaş ve Gür, 2020; Karaağaç Cingöz ve Gür, 2020; Suna vd., 2020a; 2020b). Dolayısıyla sorunların şiddeti bir lise türünden diğer lise türüne değişmektedir. Sonuç olarak liselere geçiş sistemleri, okullar arası başarı farkları veya eğitimde eşitsizliklerin daha görünür olmasında veya şiddetinin artmasında önemli rol oynayabilmektedir.

Türkiye'de liseler arasındaki başarı farklılıkları ve oluşturulan hiyerarşi, ortaöğretimin en temel sorunu olarak ön plana çıkmaktadır (Gür vd., 2013). Eğitim sistemi ile ilgili uluslararası karşılaştırmalar ve değerlendirmelerde de liseler arasında başarı farklılıklarının yüksekliği vurgulanmaktadır (Dünya Bankası, 2013; OECD, 2010; Suna, Tanberkan ve Özer, 2020). Bu durumun temel sebebi, Türkiye'de temel eğitimde var olan ve yeterince telafi edilemeyen okullar arası başarı farkları şiddetinin liselere geçiş sistemi ile artmasıdır (Özer, 2020a). Böylece, öğrenciler akademik başarılarına göre lise türlerinde nispeten homojen bir şekilde kümelenmektedir. Öğrencilerin akademik başarılarına göre okul türlerine gruplanması okul ayrıştırması olarak nitelendirilmekte olup bu gruplamanın eğitimde eşitsizlikleri artırdığı birçok çalışmada gösterilmiştir (Hanushek ve Woessmann, 2006; Özer ve Perc, 2020).

Tüm bu çalışmalar, liselere geçiş sistemlerinde mevcut sistemin iyileştirilmesi kapsamında kısmi revizyonların ötesinde köklü değişiklik yapıldığında sistem üzerinde öngörülemeyen farklı etkilere yol açabildiğini göstermektedir. Bu bağlamda, bu etkilerin belirlenmesine yönelik yapılacak farklı çalışmalar bir taraftan bu değişikliklerin sonrasında yol açtığı ve halen yaşanan bazı sorunların kaynaklarını doğru bir şekilde belirlenmesine diğer taraftan da sonraki yıllarda yapılabilecek değişikliklerin maliyet hesaplarının doğru bir şekilde hesaplanabilmesine katkıda bulunacaktır. Bu nedenle bu çalışmada, Türkiye'de ortaöğretime geçiş sistemlerinde yapılan kapsamlı/sistemik değişikliklerin öğrenci başarısına etkisi araştırımaktadır. Bu kapsamda, 2010-2019 yılları arasında ortaöğretime geçiş sistemlerinde yapılan değişikliklerin öğrencilerin ortaöğretimin ilk yılındaki (dokuzuncu sınıf) matematik dersi başarıları üzerine etkisi incelenmiştir. Dokuzuncu sınıf, öğrencilerin kademeler arası geçiş sonrası akademik performanslarının ölçüldüğü ilk sınıf düzeyidir. Kademeler arası geçiş sisteminin oluşturduğu olası etkiye dair ilk sonuçların bu sınıf düzeyinde ortaya çıkması nedeniyle dokuzuncu sınıftaki akademik başarı dikkate alınmıştır. Matematik başarısının tercih edilmesinin temel nedenleri ise ulusal ve uluslararası başarı izleme çalışmalarında dikkate alınan temel alanlardan birisi olması ve diğer başarı ölçütlerine göre daha fazla değişkenlik gösterebilmesidir. Makale kullandığı veri seti, yöntemi ve kapsamı itibarıyla birçok 
GÜR, ÖZTÜRK, ÖZER \& SUNA - Çukurova Üniversitesi Eğitim Fakültesi Dergisi, 50(2), 2021, 1437-1463

açıdan özgündür. Birincisi, çalışmada 2010-2019 yılları arasında ilköğretimden ortaöğretime geçiş yapan tüm öğrencilerin verileri kullanılmıştır. Bugüne kadar hiçbir akademik çalışmada böylesine kapsamlı bir veri seti kullanılmamıştır. İkincisi, Türkiye'de ortaöğretime geçiş sistemlerindeki değişikliklerin öğrencilerin başarısına etkisi ampirik olarak ve 9. sınıf öğrencilerinin okul başarıları matematik dersi özelinde incelenerek ilk defa ortaya konmuştur. Bu inceleme yapılırken yıllar arasında değişkenliğe yol açan ve başarı üzerinde etkisi olabilecek yaş, cinsiyet, anne ve baba eğitim düzeyi ile öğrencilerin sekizinci sınıf matematik başarıları kontrol edilmiştir. Çalışmada ayrıca, ampirik araştırmanın sonuçlarına dayalı olarak Türkiye'deki eğitim politikalarına ilişkin öneriler sunulmaktadır.

Araştırma amacı doğrultusunda aşağıdaki sorulara cevap aranmıştır:

- $\quad$ Kademeler arası geçiş sistemlerinde yapılan değişikliklerin ardından öğrencilerin matematik başarıları nasıl değişim göstermektedir?

- Kademeler arası geçiş sistemlerinde yapılan değişikliklerin ardından öğrencilerin matematik başarıları öğrencilerin cinsiyet, yaş, veli eğitim düzeyi ve sekizinci sınıf başarıları kontrol edildiğinde nasıl değişim göstermektedir?

\section{Ortaöğretime Geçiş Sistemlerinde Yapılan Değişiklikler}

Türkiye'de kademeler arası geçişlerde birkaç yıl aralıklarla değişiklikler yapılmaktadır. Bunun temel nedeni, merkezi sınavların tüm eğitim sistemini olumsuz etkilemesi (ör. öğrencileri stres ve kaygıya itmesi, özel ders ve kursa yönelimin artması vb.) yönündeki eleştirilerdir (Çelik, 2012). Dolayısıyla, sınav sistemlerinin eğitim sisteminde en büyük sorun alanı olarak görülmesi, bu sistemlerde yapılacak iyileştirmelerin aynı zamanda tüm eğitimde iyileşmeye yol açacağı varsayımına dayanmaktadır. Bu değişikliklerle okul dışı kaynaklara ve dershaneye olan bağımlılığı azaltmak, okulu merkeze almak, öğrenci yetenek ve yeterliliklerini daha iyi tespit etmek, sınav stresini azaltmak ve eğitim kalitesini artırmak amaçlanmıştır (Gür ve Çelik, 2009).

2000'li yıllar boyunca Türkiye'de Ortaöğretim Kurumları Sınavı (OKS), SBS'ler ve SBS, TEOG ve son olarak LGS gibi düzenlemeler yapılmıştır (Tablo 1). Her ne kadar farklı yıllarda ortaöğretime geçişte temel belirleyici merkezi sınavlar olmaya devam etse de sınavların adı, içeriği, uygulanma biçimi ve puan hesaplama yöntemi ile yerleştirme sistemi gibi konularda sürekli değişiklikler olduğu görülmektedir (Alpaydın, 2018; Biçer, 2014; Çelik, 2012; Gür vd., 2013). 2018 yılından itibaren uygulanan LGS ile birlikte, öğrencilerin yaklaşık \%10'nun sınav puanlarına göre, geriye kalan kısmına ise okul başarı puanına göre tercihlerine yerleştirme sistemine geçilmiştir.

Tablo 1.

Ortaöğretime Geçiş Sisteminde Yapılan Değişiklikler (2000-günümüz).

\begin{tabular}{cl}
\hline Geçiş Sistemi & Uygulama Süresi \\
\hline OKS & 2004-2005 öğretim yılında başladı \\
& 2007-2008 yılında son kez uygulandı \\
\hline SBS'ler & 2008'den itibaren 6. ve 7. sınıflara uygulandı \\
& 2009'dan itibaren 6., 7. ve 8. sınıflara da uygulandı \\
& 2010-2011'de sadece 7. ve 8. sınıflarda uygulandı \\
\hline SBS & 2011-2012'de 8. sınıflara uygulandı \\
& 2012-2013'de 8. sınıflara son kez uygulandı \\
\hline
\end{tabular}


TEOG 2013-2014 öğretim yılında başladı 2016-2017'de son kez uygulandı

LGS

2017-2018 öğretim yılında 8. sınıflarda başladı 2020 yılı itibarıyla 8. sınıflarda devam ediyor

Yıllara göre merkezi sınava girip tercih yaparak liselere yerleşen öğrenci sayıları Tablo 2'de verilmiştir. Tüm kademeler arası geçiş sistemlerinde öğrencilerin akademik performansına göre liselere yerleştirmede merkezi sınav puanı ile ayrıştırmanın en düşük düzeyde gerçekleştirildiği sistemin LGS olduğu görülmektedir.

Tablo 2.

Yıllara Göre Merkezi Sınava Giren ve Merkezi Sınavla Ortaöğretime Yerleşen Öğrenci Sayısı.

\begin{tabular}{|c|c|c|c|c|c|}
\hline Öğretim yılı & $\begin{array}{l}\text { Geçiş } \\
\text { Sistemi }\end{array}$ & $\begin{array}{l}\text { 8. sınıf mezun } \\
\text { sayısı }\end{array}$ & $\begin{array}{l}\text { Tercih } \\
\text { yapan } \\
\text { öğrenci } \\
\text { sayısı }\end{array}$ & $\begin{array}{r}\text { Merkezi sınavla } \\
\text { ortaöğretime } \\
\text { yerleşen kişi } \\
\text { sayısı }\end{array}$ & $\begin{array}{r}\text { Merkezi sınavla } \\
\text { ortaöğretime } \\
\text { yerleşen öğrenci } \\
\text { oranı }\end{array}$ \\
\hline 2010-2011 & SBS & 1.228 .634 & 668.117 & 366.762 & 29,85 \\
\hline 2011-2012 & SBS & 1.254 .660 & 777.096 & 315.770 & 25,17 \\
\hline 2012-2013 & SBS & 1.240 .556 & 904.114 & 626.207 & 50,48 \\
\hline 2013-2014 & TEOG & 1.257 .324 & 1.136 .546 & 1.057 .799 & 84,13 \\
\hline 2014-2015 & TEOG & 1.256 .306 & 1.108 .182 & 1.036 .809 & 82,53 \\
\hline $2015-2016$ & TEOG & 1.147.179 & 1.001 .975 & 956.190 & 83,35 \\
\hline 2016-2017 & TEOG & 1.167 .536 & 1.019 .577 & 935.241 & 80,10 \\
\hline 2017-2018 & LGS & 1.155 .294 & 437.070 & 127.283 & 11,02 \\
\hline 2018-2019 & LGS & 1.187 .260 & 439.419 & 138.993 & 11,71 \\
\hline $2019-2020$ & LGS & 1.670 .258 & 568.627 & 206.619 & 12,37 \\
\hline
\end{tabular}

\section{Yöntem}

\section{Araştırma Modeli}

$\mathrm{Bu}$ çalışma, son on yılda liseye geçiş sistemlerinde yapılan değişimlerin öğrencilerin matematik başarısı üzerindeki etkisini belirlemeyi amaçlamaktadır. Araştırma amacı doğrultusunda çalışma 
GÜR, ÖZTÜRK, ÖZER \& SUNA - Çukurova Üniversitesi Eğitim Fakültesi Dergisi, 50(2), 2021, 1437-1463

nedensel karşılaştırma deseni kullanılarak tasarlanmıştır. Nedensel araştırmalarda ortaya çıkmış ya da daha önce gerçekleşmiş durumların nedenleri veya sonuçları incelenmektedir (Creswell, 2014; Salkind, 2010). Deneysel araştırmalardan farklı olarak bu çalışmalarda, bağımsız değişken araştırmacılar tarafından manipüle edilemez ve incelenen durum geçmiş zaman gerçekleştiği için deneysel kontrol imkânı bulunmamaktadır. Nedensel karşılaştırma çalışmalarında etkinin deneysel olarak test edilememesi dolayısıyla elde edilen sonuçlar yorumlanırken bağımlı değişken üzerinde etkisi olabilecek diğer faktörlerin de dikkate alınması gerekmektedir (Salkind, 2010). Bu araştırmanın bağımsız değişkeni olan kademeler arası geçiş sistemlerindeki değişimler araştırmacılar tarafından manipüle edilememekte ve bağımlı değişken olan öğrencilerin matematik başarısı geçmiş zamanda gerçekleşmektedir. Öğrencilerin dokuzuncu sınıf matematik başarısına etki edebilecek olası değişkenlerin etkisi dikkate alınmıştır.

\section{Araştırma Evreni}

Araştırmada Türkiye'de son on yılda 9. sınıfta eğitime devam eden öğrenci evrenine ilişkin veriler kullanılmıştır. Araştırma verileri, 2010-2011 ile 2019-2020 öğretim yılları arasında 9. sınıfta eğitime devam eden toplam 12 milyon 230 bin 358 öğrenciden oluşmaktadır. Araştırmada yer alan öğrencilerin yıllara göre sayıları ve cinsiyet dağılımları Şekil 1'de verilmiştir.

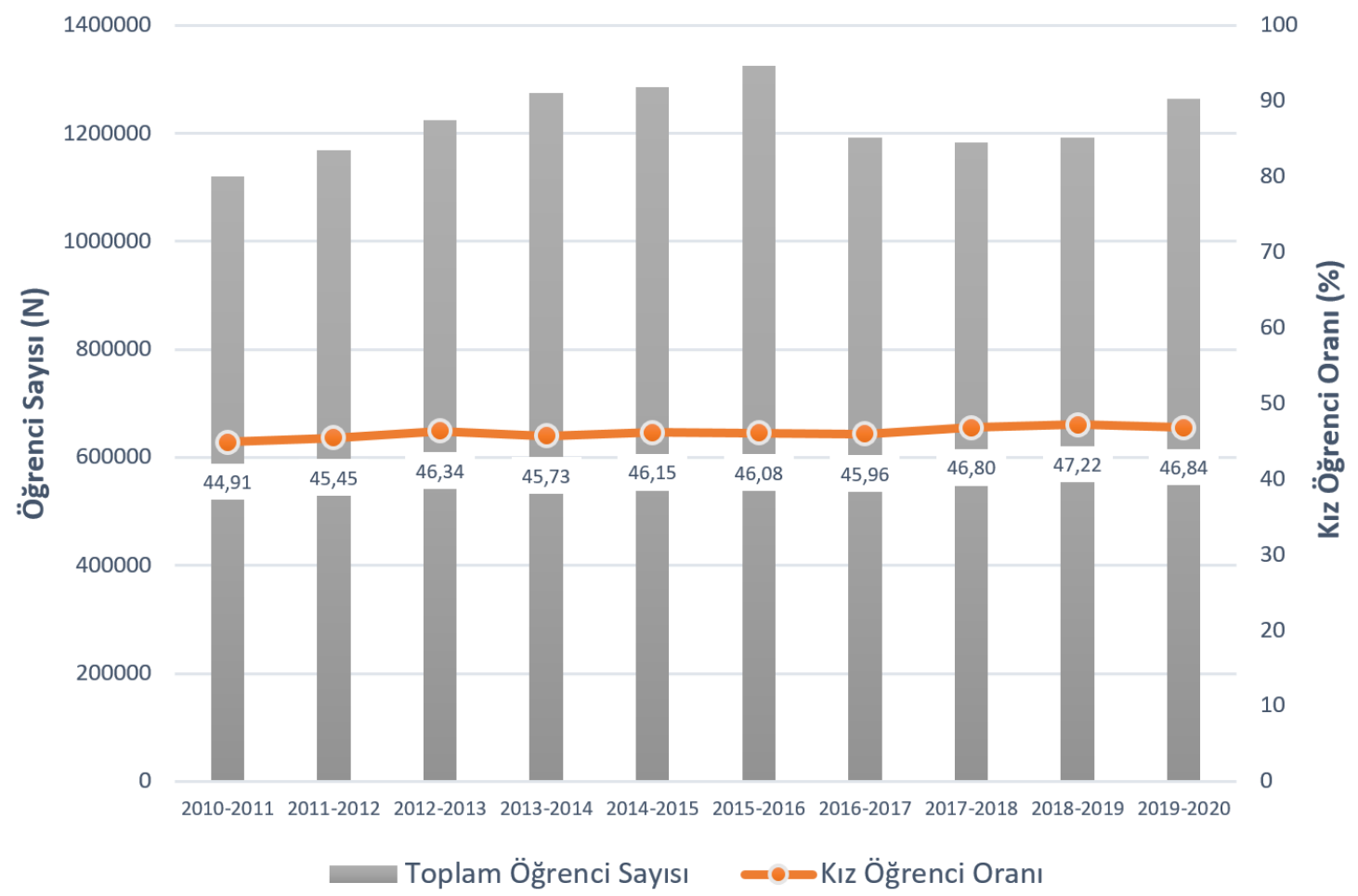

Şekil 1. Araştırma Evrenindeki Öğrencilerin Yıllara ve Kız Öğrenci Oranına Göre Dağılımı

Şekil 1'de görüldüğü gibi araştırmada yer alan öğrencilerin eğitim yıllarına göre sayıları 1.119.894 ile 1.324.604 arasında değişmektedir. Öğrencilerin cinsiyet gruplarına dağılımı yıllar içinde yalnızca küçük değişimler göstermektedir. Buna göre, veri setindeki erkek öğrencilerin oranı yıllar içinde \%52,78 ile $\% 55,09$ arasında, kız öğrencilerin oranı ise \%44,91 ile \%47,22 arasında değişmektedir. Dolayısıyla öğrenci evreni cinsiyet grupları açısından dengeli bir dağılıma sahiptir. 


\section{Veri Analizi}

Araştırma amacı doğrultusunda 2010-2011 ve 2019-2020 yılları arasında öğrencilerin sekizinci ve dokuzuncu sınıflardaki akademik başarılarının göstergesi olarak matematik dersi yazılı notları dikkate alınmıştır. Kademeler arası geçiş sisteminin yapısı dolayısıyla bazı eğitim yıllarında sekizinci sınıfın ikinci yazılı sınavlarının merkezi yapılması dolayısıyla tüm yıllardaki ilk ve üçüncü yazılı notlarının ortalaması dikkate alınmıştır. Dokuzuncu sınıfta ise bazı yıllarda üçüncü yazılının yapılmaması nedeniyle yapılması zorunlu olan ilk iki yazılı notlarının ortalaması dikkate alınmıştır. Böylece sınıf değerlendirmeleri bağlamında öğrencilerin performanslarının yıllara göre ve sınıf düzeylerine göre karşılaştırılması sağlanmıştır. Öğrencilerin matematik dersi başarı puanlarının tüm yıllarda 0 ile 100 arasında değişmesi nedeniyle herhangi bir standartlaştırma işlemi uygulanmamıştır. Bu şekilde, farklı yıllarda hesaplanan puan ortalamalarındaki değişimin yalın bir şekilde yorumlanması sağlanmıştır.

Araştırmada sekizinci ve dokuzuncu sınıf öğrencilerinin matematik başarılarının yıllara göre değişimi ve sistem değişikliklerinin etkisini incelemek için iki aşamalı bir süreç izlenmiştir. Birinci aşamada, dokuzuncu sınıf öğrencilerinin sekizinci ve dokuzuncu sınılardaki matematik dersi başarı puanlarının yıllara göre değişimi betimsel olarak incelenmiştir. Bu aşama, son on yılda matematik başarılarındaki değişimi herhangi bir istatistiksel kontrol yapılmadan göstermesi açısından önemlidir.

İkinci aşamada, 9. sınıf öğrencilerinin bu değişimin ardışık yıllardaki değişimi harici değişkenler kontrol edilerek incelenmiştir. Harici değişkenlerin kontrolü, araştırmada konu edilmeyen çeşitli ailevi ve kişisel değişkenlerin başarı üzerindeki etkisinin elimine edilmesi sağlamaktadır. Bilindiği üzere, nedensel karşılaştırma araştırmalarının iki temel sınırlılığı deneysel kontrolün eksikliği ve bağımsız değişkenin manipüle edilememesidir (Creswell, 2014). Deneysel kontrolün eksikliğini telafi edebilmek için istatistiksel kontrol yöntemleri önemli imkânlar sunmaktadır. Bu imkânı kullanabilmek için çalışmada öğrencilerin e-okul sistemindeki demografik ve kişisel verileri incelenmiş, akademik başarı üzerinde anlamlı bir etkiye sahip olduğu çeşitli araştırmalarda gösterilen değişkenlerin önceki başarıları, yaşları, cinsiyetleri ve veli eğitim düzeyi olduğu görülmüştür (MEB, 2018, 2019b, 2020; OECD, 2019b; Pellizzari ve Billari, 2011). Bu değişkenlerin etkisinin istatistiksel olarak kontrol edilebilmesi için çoklu doğrusal regresyon analizi gerçekleştirilmiştir. Analiz sürecinde etkisi kontrol edilen değişkenlerin tümünün dâhil edildiği regresyon modeli aşağıda verilmiştir:

$$
y i j=\propto+j d i j+X i \Pi+i
$$

Bu denklemde, i öğrencinin j öğretim yılında 9. sınıf matematik yazılı not ortalamasını, bir kukla değişken olup i öğrencinin j öğretim yılında 9. sınıfta olması durumunda 1 değerini almasını, kontrol edilen diğer kişisel değişkenleri ve ise hata terimini göstermektedir. Kişisel kontrol değişkenleri, öğrencinin 8. sınıf matematik yazılı not ortalaması, yaş, cinsiyet ve anne ile baba eğitimini temsilen en yüksek eğitim seviyesine sahip ebeveynin bitirdiği okul düzeyine denk gelen ortalama tamamlanan eğitim yılından oluşmaktadır. Böylece değişkeni için hesaplanan katsayısı, harici değişkenlerin etkisinden arındırılmış önceki yıla göre 9. sınıf matematik başarı değişimini vermektedir.

Bu aşamada, son on yıllık sürede öğrencilerin matematik başarılarının bir önceki yıla göre değişimini harici değişkenlerin etkisini elimine ederek hesaplamak için (1) modeli kullanılarak dokuz regresyon eşitliği kurulmuştur. Örneğin 2011 yılının 2010 yılına göre ortalama not değişimini tahmin eden regresyon denkleminde, 2011 öğretim yılında 9. sınıfta yer alan öğrenciler için kukla değişkeni 1 değerini, 2010 öğretim yılında 9. sınıfta yer alan öğrenciler içinse , 0 değerini almaktadır. 2011 yılında elde edilen değeri anlamlı ise, bu yılda hesaplanan ortalamanın 2010 yılının ortalamasından anlamlı ölçüde farklı olduğu ifade edilmiştir.

Analizlerde öğretim yılı, okulun başlangıç yılı ile anılmıştır. Örneğin, 2010 öğretim yılı 2010-2011 öğretim yılını belirtmektedir. Veli eğitim düzeyi değişkeninin oluşturulmasında düzenleme yapılması 
gerekmiştir zira e-Okul veri setinde sadece velilerin bitirdiği okul düzeyi bulunmaktadır. Ortalama tamamlanan eğitim yılı tahmininde; okuma yazma bilmeyenler 0 , okuma yazma bilenler ve ilköğretim öğrencileri 2 yıl, ilkokul mezunları 5 yıl, ortaokul ve ilköğretim mezunları 8 yıl, lise mezunları 11 yıl, yüksekokul mezunları 13 yıl, 3 yıllık eğitim enstitüleri mezunları 14 yıl, lisans mezunları 15 yıl, yüksek lisans mezunları 17 yıl ve doktora mezunları 20 yıl olarak kabul edilmiştir. Benzer yaklaşımlar Aydemir ve Kırdar (2017) ile Öztürk ve Tümen (2018) çalışmalarında da kullanılmıştır.

Regresyon modellerinde kullanılan tahmin modeli en küçük kareler yöntemidir. Aynı okul içinde yer alan öğrencilerin hata terimlerinin birbirleriyle ilişkili olabileceğinden hata terimleri tüm regresyon tahminlerinde okul düzeyinde kümelendirilmiştir. Öğrenci evreni verileriyle çalışılması veri hacminin çok büyük olmasına ve en küçük farklılıkların dahi istatistiksel olarak anlamlı olmasına yol açmaktadır. Bu nedenle ilk araştırma sorusuna dair değerlendirmede ortalama puanlar arası farkların anlamlılığı test edilmemiştir.

İkinci adımda kontrol edilen değişkenlerde önemli oranlarda kayıp veriler bulunmaktadır ve yalnızca tüm verileri e-Okul sistemine kayıtlı olan öğrencilerin verileri kullanılmıştır. Bu durum öğrenci evreninde daralmaya yol açtığı için yapılan regresyon analizinde hesaplanan katsayıların anlamlılığı dikkate alınmıştır.

Araştırma verileri Milî Eğitim Bakanlığı Bilgi İşlem Dairesinin 65968543/622.01-E.16394512 nolu izniyle kullanılmıştır.

\section{Bulgular}

Ortaöğretime geçiş sınav sistemlerinde yaşanan değişimlerin 9. sınıf öğrencilerinin matematik başarısına etkisi incelenirken ilk aşamada herhangi bir istatistiksel kontrol olmaksızın betimsel karşılaştırma yapılmıştır. Geçiş sistemlerinin etkisine dair detaylı bir inceleme yapabilmek adına son on yıllık sürede 9. sınıfa kayıtlı öğrencilerin matematik başarı ortalamaları, bu öğrencilerin sekizinci sınıftaki başarı ortalamaları ile birlikte incelenmiş ve sonuçlar Şekil 2'de verilmiştir.

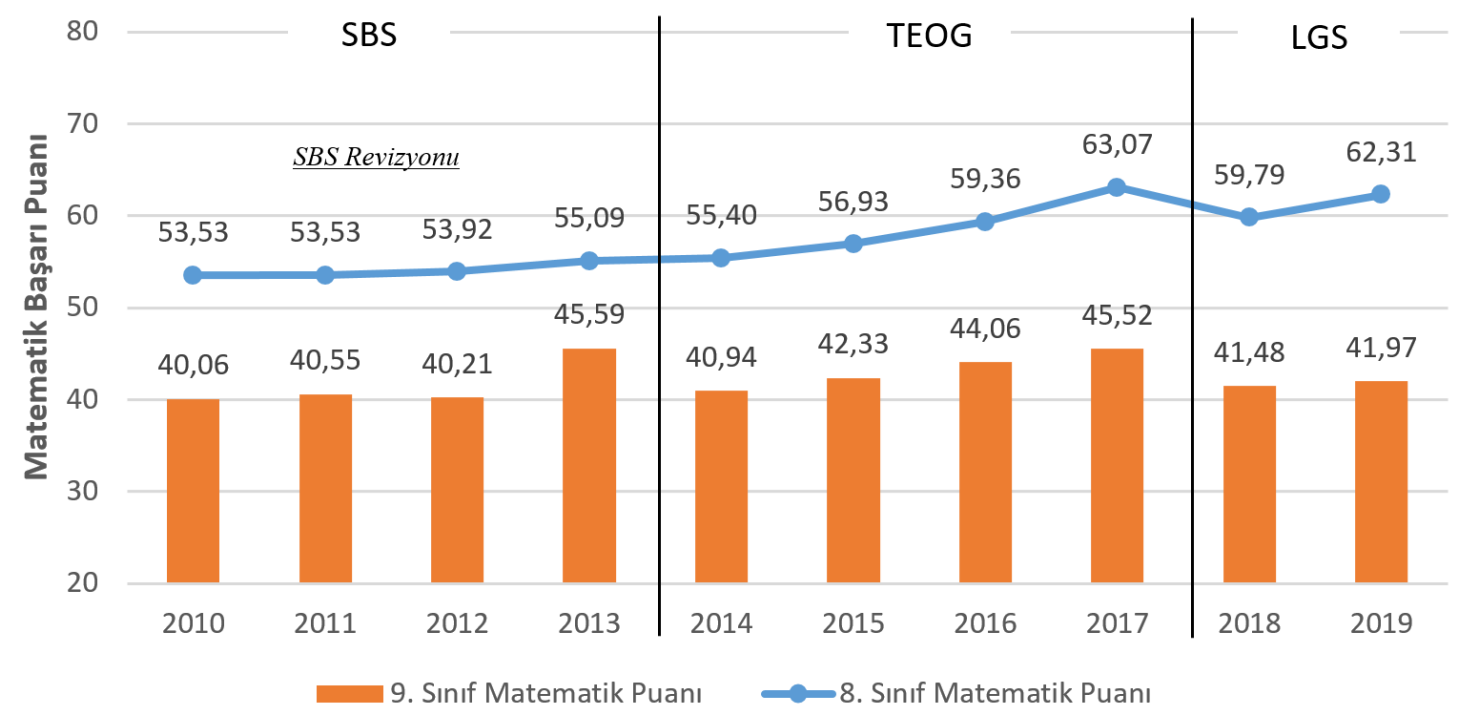

Şekil 2. Öğrencilerin 8. ve 9. Sınıf Matematik Notlarının Yıllar Içerisindeki Değişimi

Şekil 2'ye göre, son on yılda 9. sınıfta bulunan öğrencilerin bu sınıf düzeyindeki matematik başarıları geçiş sistemindeki değişimlere göre önemli değişimler göstermektedir. 2013 ile 2014 yılları arasında gerçekleşen TEOG geçişinde dokuzuncu sınıf öğrencilerinin puan ortalamaları yaklaşık 4,55 puan (\%10) 
düşüş göstermiştir. Benzer bir şekilde, 2017 ile 2018 yılları arasındaki LGS'ye geçişte de matematik başarısı ortalaması 4,04 puan $(\% 8,88)$ düşmüştür. Buna karşın, 2011 ile 2012 yılları arasında SBS'nin kendi içindeki revizyonunda görülen değişimin son derece sınırlı olduğu (0,34 puan, \%1'in altında) görülmektedir. 9. sınıf ortalamalarında görülen diğer bir önemli durum da her üç geçiş sisteminde de yıllar içinde matematik başarısının genel olarak artma eğiliminde olmasıdır. Dolayısıyla, geçiş sistemindeki değişiklikten kaynaklı oluşan etkinin öğrenci notlarında bir düşüşe sebep olduğu ancak zaman içinde ortalamanın tekrar artışa geçtiği ifade edilebilir.

Dokuzuncu sınıf öğrencilerinin sekizinci sınıf matematik başarıları incelendiğinde ise sınav sistemlerinin ikincil etkilerine dair bulgular elde edilmektedir. Şekil 2'de görüldüğü gibi, öğrencilerin sekizinci sınıf ortalamalarını üç grupta toplamak mümkündür. 2010 ile 2013 yılları aralığındaki değişimi ifade eden ilk grupta, matematik ortalamalarının birbirine oldukça yakın olduğu, 2013 yılında kısmen arttığı görülmektedir. 2014 ile 2017 arasındaki ikinci grupta ise matematik başarısı sürekli ve daha yüksek oranlarda artış göstermektedir. 2018 ve 2019 yıllarından oluşan üçüncü grupta ise başarı ortalaması önce düşmekte ardından artış göstermektedir.

Sekizinci sınıf matematik puanlarının değişim eğilimine göre oluşturulan bu üç grubun geçiş sistemleri ile ilişkisi dikkate alındığında iki sonuç öne çıkmaktadır. Bu sonuçlardan ilki, puanların büyük oranda artış gösterdiği ikinci grubun TEOG'un uygulandığı yıllarda gerçekleşmesidir. Bu bağlamda TEOG, SBS ve LGS'den farklı olarak puanların daha büyük oranlarda ve sürekli artış gösterdiği tek geçiş sistemi olmuştur. Geçiş sistemlerinde en düşük ve en büyük ortalamalar arasındaki yüzde farkı incelendiğinde, SBS' de farkın \%2,91, TEOG'da \%13,84 ve LGS'de \%4,21 olduğu görülmektedir. Dolayısıyla TEOG, sistem içindeki ortalama puan artışının en yüksek olduğu geçiş sistemi olmuştur. TEOG ile yapılan yerleştirme sürecinde okul puanının etkili olması, bu büyük artışın temel sebeplerinden birisi olabilir. Öne çıkan ikinci sonuç, her üç geçiş sisteminde de geçişin yaşandığı yıllardan sonra puanların artma eğiliminde olmasıdır.

Araştırmanın ilk kısmında elde edilen bulgular, sistem geçişlerinin ardından yaşanan puan değişimi örüntülerinin her iki sınıf düzeyinde de genel bir benzerlik gösterdiğine işaret etmektedir. Şekil 2'de görüldüğü gibi, 9. sınıf öğrencilerinin ortalamaları ile bu öğrencilerin 8. sınıftaki ortalamaları geçiş sistemlerinden sonra benzer bir yönelim göstermektedir. Bununla birlikte, 9. sınıf başarısında görülen değişimler geçiş sistemlerindeki değişimlerin oluşturduğu şokları daha açık göstermektedir.

Araştırmanın ikinci aşamasında, geçiş sistemlerinin etkisi incelenirken hem harici değişkenlerin etkisi kontrol edilmiş hem de değişimin ardışık yıllara göre nasıl değiştiğine odaklanılmıştır. Bu amaç doğrultusunda gerçekleştirilen regresyon katsayıları Tablo 3'te verilmiş, beta katsayılarının değişimi Şekil 3'te gösterilmiştir.

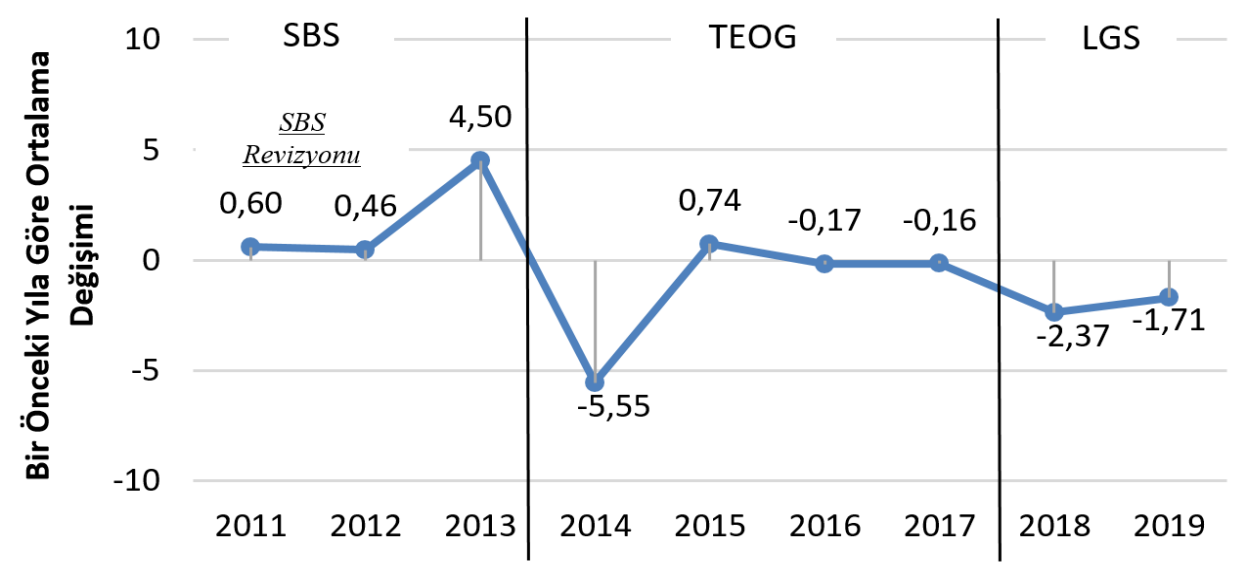

Şekil 3. Öğrencilerin 9. Sınıf Matematik Notlarının Yıllar Iç̧erisindeki Değişimi 
Tablo 3.

Ardışık Yıllara Göre Yapılan Regresyon Analizi Sonuçları.*,**

\begin{tabular}{|c|c|c|c|c|c|c|c|c|c|}
\hline & $\begin{array}{l}2011- \\
2010\end{array}$ & $\begin{array}{l}2012- \\
2011\end{array}$ & $\begin{array}{l}2013- \\
2012\end{array}$ & $\begin{array}{l}2014- \\
2013\end{array}$ & $\begin{array}{l}2015- \\
2014\end{array}$ & $\begin{array}{l}2016- \\
2015\end{array}$ & $\begin{array}{l}2017- \\
2016\end{array}$ & $\begin{array}{l}2018- \\
2017\end{array}$ & $\begin{array}{l}2019- \\
2018\end{array}$ \\
\hline Sabit & 25,29 & 25,10 & 26,93 & 30,67 & 22,68 & 21,48 & 18,63 & 9,17 & $-5,16$ \\
\hline Beta & $0,60^{*}$ & $0,46^{*}$ & $4,50^{*}$ & $-5,55^{*}$ & $0,74^{*}$ & $-0,17$ & $-0,16$ & $-2,37 *$ & $-1,71 *$ \\
\hline 8. Sinıf Puanı** & $0,56^{*}$ & $0,56^{*}$ & $0,51^{*}$ & $0,50^{*}$ & $0,52^{*}$ & $0,52^{*}$ & $0,53^{*}$ & $0,59 *$ & $0,58^{*}$ \\
\hline Cinsiyet** & $2,94^{*}$ & $3,15^{*}$ & $2,57^{*}$ & $2,00^{*}$ & $2,02^{*}$ & $2,05^{*}$ & $2,25^{*}$ & $1,79 *$ & $1,86^{*}$ \\
\hline Yaş** & $-1,24^{*}$ & $-1,19 *$ & $-1,09 *$ & $-0,94 *$ & $-0,88^{*}$ & $-0,77^{*}$ & $-0,60 *$ & $-0,21 *$ & $0,54^{*}$ \\
\hline Veli Eğitimi** & $0,21^{*}$ & $0,24^{*}$ & $0,20 *$ & $0,15^{*}$ & $0,22^{*}$ & $0,23 *$ & $0,19^{*}$ & $0,25 *$ & $0,48^{*}$ \\
\hline
\end{tabular}

${ }^{*} p<0,01,{ }^{*}$ Kontrol değişkenleri

Şekil 3 ve Tablo 3’te görüldüğü gibi, öğrencilerin kişisel ve ailevi değişkenleri kontrol edildiğinde de sistem değişikliklerinin olduğu yıllarda öğrencilerin matematik başarılarının anlamlı ölçüde düştüğü görülmektedir. Özellikle 2013-2014 öğretim yılında TEOG ile birlikte tüm öğrencilerin okullara TEOG puanına göre yerleştirilmesi sonucunda 9. sınıf öğrenci başarısında keskin bir düşüş yaşanmıştır $(\beta=-5,55$, p<0,01). 2018-2019 yılında ise LGS sistemine geçilmesi sonucunda öğrenci başarısında tekrar bir düşüş yaşanmıştır. Ancak, LGS'ye geçişte yaşanan düşüşün şiddeti TEOG'a göre daha düşük düzeyde kalmıştır $(b=-2,37, p<0,01)$. Temel olarak sınav sistemindeki esaslı değişikliklerin (TEOG ve LGS) yapıldığı yıllarda ortalama öğrenci başarısında düşüşler yaşanmış, sistem değişikliği yapılmayan 2014, 2015, 2016 yıllarında ise istatistiksel olarak anlamlı olmayan ya da küçük değişimler yaşanmıştır.

Diğer taraftan, 2011 yılından 2012 yılına geçildiğinde SBS revizyonunun yapılmasının, öğrencilerin 9. sınıf matematik başarısında olumsuz bir yansıması olmadığı, hatta ortalamanın anlamlı ölçüde arttığı görülmektedir $(b=0,46, p<0,01)$. Dahası, sınav sistemlerinde herhangi bir değişikliğin olmadığı 2013 yılında 9. sınıf öğrenci başarısının 2012 yılına göre önemli ölçüde yükseldiği görülmektedir.

Bulgular bir bütün olarak değerlendirildiğinde, harici değişkenlerin kontrol edilmediği ve edildiği her iki durumda da geçiş sistemlerindeki değişikliklerin matematik başarısı üzerinde olumsuz etkileri olduğu görülmektedir. Araştırmanın ilk kısmında görüldüğü üzere, sistem değişikliklerinin 9. sınıf başarısına ek olarak 8. sınıf puanları üzerinde de ikincil etkileri olabilmektedir. Sistem müdahalesinin yapılmadığı ya da sistem içinde değişimlerin sınırlı kaldığı yıllarda 9. sınıf öğrenci başarısının artma eğiliminde olduğu görülmektedir.

\section{Tartışma ve Sonuç}

Kademeler arası geçiş sistemleri, Türkiye'de ortaöğretim ve yükseköğretime geçiş sürecinde öğrencilerin seçimi için kullanılan süreçlerdir. Türkiye'de ortaöğretime geçişte kullanılan sistemler özellikle 2000'li yıllardan sonra önemli yapısal değişimler göstermiştir. Bu yapısal değişimlerin oluşturduğu sonuçların değerlendirilmesi önemli olmakla beraber bu konudaki ampirik çalışmaların oldukça sınırlı olduğu görülmektedir (Küçüker, 2017; Suna vd., 2020a; TED, 2010). Geçiş sistemlerini konu edinen çalışmalar sıklıkla bu sistemler kapsamındaki merkezi sınavda gösterilen performansla ilişkili değişkenleri belirlemeyi amaçlamaktadır (Akay, 2017; Anasız, Ekinci ve Anasız, 2018; Aslan, 2017; 
Karaağaç Cingöz ve Gür, 2020). Bu çalışmalarda merkezi sınav performansının öğrencilerin sosyoekonomik düzeyi, okulöncesi eğitime katılımı, okuma alışkanlıkları ve okul imkânları gibi çeşitli özelliklerle ilişkili olduğu gösterilmiştir. Diğer bazı çalışmalar ise öğrenciler, öğretmenler ve okul yöneticilerinin kademeler arası geçiş sistemlerine dair görüşlerine odaklanmaktadır (Baş ve Kıvıııım, 2019; Karakaya, Bulut ve Yılmaz, 2020; Özkan, Karataş, 2016; Şahin vd., 2012). Sınav sisteminin öğrencilerin davranışları ve tutumları üzerinde belirleyici olduğu, dolayısıyla sınav sistemleri arasındaki değişimlerin bu davranış ve tutumlar üzerinde de farklılıklar oluşturabileceği görülmektedir. Dolayısıyla sınav sistemlerindeki değişimler yapısal özellikleri ve öğrenci yaşantılarına yönelik etkileri ile öğrencilerin başarısı üzerinde etkili olma potansiyeline sahiptir.

Bu çalışmada, liselere geçiş sistemlerinde yapılan değişikliklerin öğrenci başarısı üzerine etkileri, öğrencilerin okul ayrıştırmasından sonra yerleştikleri liselerin ilk yılındaki matematik başarıları üzerinden araştırılmıştır. Elde edilen bulgular genel olarak değerlendirildiğinde, ortaöğretime geçiş sisteminde kapsamlı değişiklikler yapıldığı yılların hemen sonrasında öğrencilerin dokuzuncu sınıf matematik başarılarında keskin düşüşler gerçekleştiği görülmektedir. Söz konusu düşüşler hem doğrudan karşılaştırmada hem de matematik başarısı ile ilişkili olan yaş, cinsiyet ve önceki akademik başarı kontrol edildiğinde tutarlı olarak elde edilmektedir. Kademeler arası geçiş sistemlerinde yapılan değişimlerin hemen sonrasında öğrencilerin matematik başarısında tutarlı bir şekilde düşüş görülmesi sistem değişikliklerinin başarı ile ilişki olduğuna işaret etmektedir. Gerçekten de 2013-2014 öğretim yılında getirilen TEOG ve 2017-2018 öğretim yılında getirilen LGS sonrasında düşüşler yaşanmıştır. Ancak, LGS sonrasında öğrenci başarısında yaşanan düşüş TEOG'a göre daha düşük düzeydedir. Diğer taraftan, kapsamlı değişiklikler yapılmadığı yıllarda ve sistem değişimi yapılmadan sistemin yapısında küçük değişiklikler yapıldığı yıllarda öğrenci başarısında olumlu bir değişimin yaşandığı görülmektedir. Araştırmada elde edilen bulgular, liselere geçiş sisteminde köklü değişiklikler yerine daha küçük ölçekli müdahalelerin daha iyi olabileceğini ortaya koymaktadır.

Diğer taraftan, yapılan çalışmanın odağını liselere geçiş sistemlerinin öğrenci başarıları üzerine etkilerini belirleme oluşturmasına rağmen 2012-2013 öğretim yılında getirilen ve $4+4+4$ olarak bilinen yasa sonrasında zorunlu eğitimin süresinin 8 yıldan 12 yıla çıkarılmasının etkisini de gözlemleme imkânı vermiştir. Çalışmada elde edilen bulgular, bu dönüşümün öğrenci başarısında bir düşüşe yol açmadığını göstermektedir. Bir başka ifadeyle, sınav sistemlerindeki değişikliklerin etkisinin $4+4+4$ gibi diğer sistemsel değişikliklerden çok daha fazla olduğu görülmektedir.

Sınav sistemlerindeki değişikliklerin öğrenci başarısında oluşturduğu değişim, bu sistemlerin eğitim üzerindeki etkisini göstermesi açısından önemlidir. Çalışma bulguları, yapısından ve getirdiği düzenlemelerden bağımsız olarak kademeler arası geçiş sistemindeki büyük değişimlerin öğrenci başarısında önemli bir değişimi beraberinde getirdiğini ve bu değişimin olumsuz yönde olduğunu göstermektedir. Daha önce çeşitli çalışmalarda gösterildiği üzere, sınav sistemlerinde yapılan düzenlemeler öğrencileri, velileri ve yöneticileri olumsuz etkilemektedir (Demirbilek ve Levent, 2019; Dinç vd., 2014; Zayimoğlu Öztürk, 2014). Bu çalışmada ise ilk defa ampirik olarak, sistemdeki büyük değişikliklerin öğrenci başarısını olumsuz etkilediği gösterilmiştir. Çalışma bulguları, ortaöğretime geçiş sisteminde yapılan kapsamlı değişimlerin öğrenci başarısı üzerindeki somut sonuçlarını net bir şekilde göstermektedir. Özetle, kademeler arası geçiş sistemlerinde yapılan tüm düzenlemelerin hemen ardından öğrencilerin okul başarııında bir düşüş gerçekleşmekte, yeni bir düzenleme yapılmadığı takdirde başarı tekrar artma eğilimine girmektedir. Bu bulgu, sistemin geçiş sistemindeki köklü değişiklik karşısında hemen tepki verdiğini ardından bu olumsuz etkinin zamanla telafi edilebildiğini ve her yeni düzenlemeden sonra benzer dalgalanmanın yaşandığııı göstermektedir.

Birçok ülkede bir yandan eğitim sisteminin bütünü düzeyinde reform çalışmaları gittikçe daha görünür olsa da (Fullan, 2009), sistem düzeyinde ve kapsamlı reform girişimlerinden uzaklaşan ve sistemin farklı tabakalarında kaliteyi artıracak kapasite geliştirme çalışmalarına (Wurzburg, 2010) odaklanmak daha makul görünmektedir. Bir başka deyişle, eğitim sisteminde kapsamlı reformlar yerine küçük 
GÜR, ÖZTÜRK, ÖZER \& SUNA - Çukurova Üniversitesi Eğitim Fakültesi Dergisi, 50(2), 2021, 1437-1463

değişikliklerin daha olumlu sonuçlar verebildiği savunulmaktadır (Corrales, 1999). Bu çalışma sonuçları da ortaöğretime geçiş sistemi bağlamında bu bulguyu desteklemektedir. Bu kapsamda, halen uygulanan sistemin esastan reform edilmesi yerine, küçük müdahalelerle iyileştirilmesi önerilmektedirler. Ayrıca, özellikle LGS kapsamında sınavla öğrenci alan kapasitenin \%10'un da altına düşürülmesi ve sosyoekonomik arka plan olarak öğrencilerin lise türlerinde heterojen olarak kümelenmelerini sağlayacak gerekli iyileştirmelerin yapılmasının kritik öneme sahip olduğu vurgulanmaktadır.

\section{Etik ilkelere Uygunluk}

Araştırmanın tasarlanması ve gerçekleştirilmesi sürecinde "Yükseköğretim Kurumları Bilimsel Araştırma ve Yayın Etiği Yönergesi" kurallarına uyulmuş ve "Bilimsel Araştırma ve Yayın Etiğine Aykırı Eylemler"den hiçbiri gerçekleştirilmemiştir. Araştırma kapsamında kullanılan veriler Millî Eğitim Bakanlığı Bilgi İşlem Dairesinin 65968543/622.01-E.16394512 nolu izniyle kullanılmıştır.

\section{References}

Akay, E. (2017). Ortaokul öğrencilerinin TEOG başarısına etki eden faktörlerin çok düzeyli analizi. (Yayımlanmamış Doktora Tezi), Eskişehir Osmangazi Üniversitesi, Eskişehir.

Akcaoglu, M., Gumus, S., Bellibas, M. S., \& Boyer, D. M. (2015). Policy, practice, and reality: Exploring a nation-wide technology implementation in Turkish schools. Technology, Pedagogy and Education, 24(4), 477-491. DOi:/10.1080/1475939X.2014.899264

Akman, A., \& Hacıfazlıoğlu, Ö. (2019). Sınıf öğretmenlerinin değişime karşı direnç gösterme nedenlerinin incelenmesi. Turkish Studies, 14(6), 2819-2840.

Atılgan, H. (2018). Türkiye'de kademeler arası geçiş: Dünü-bugünü ve bir model önerisi. Ege Eğitim Dergisi, 19(1), 1-18.

Alpaydın, Y. (2018). Geleceğin Türkiyesinde eğitim. İLKE Illim Kültür Eğitim Derneği.

Anasız, B, T. Ekinci, C, E. Anasız, B, Y. (2018). The impact of pre-primary education on students' academic achievement in later schooling years: TEOG exams. Inonu University Journal of the Faculty of Education, 19(2), 154-173.

Aydemir, A., \& Kirdar, M. G. (2017). Low Wage Returns to Schooling in a Developing Country: Evidence from a Major Policy Reform in Turkey. Oxford Bulletin of Economics and Statistics, 79, 1046-1086.

Aydın Baş, E., \& Şentürk, i. (2017). Eğitim Kurumları Yöneticilerinin Görevlendirilmelerine illişkin Yönetmelik hakkında okul yöneticilerinin görüşleri. Ondokuz Mayıs Üniversitesi Eğitim Fakültesi Dergisi, 36(2), 119-143. Doi:/10.7822/omuefd.373031

Aykaç, N., \& Atar, E. (2014). Geçmişten günümüze ilköğretimden ortaöğretime geçiş sisteminin değerlendirilmesi. A. Akdoğanbulut İnsan \& A. Yavuz Akengin (Ed.), Cumhuriyet'in Kuruluşundan Günümüze Eğitimde Kademeler Arası Geçiş ve Yeni Modeller Uluslararası Kongresi (ss. 83-104) içinde. Ankara: Atatürk Kültür, Dil ve Tarih Yüksek Kurumu.

Baş, G., \& Kıvılcım, Z. S. (2019). Türkiye'de öğrencilerin merkezi sistem sınavları ile ilgili algıları: Bir metafor analizi çalışması. Eğitimde Nitel Araştırmalar Dergisi, 7(2), 639-667.

Biçer, D. (2014). Ortaöğretime geçiş sürecinin Almanya ve Rusya örnekleriyle karşılaştırılması ve yaşanan sorunlara çözüm önerileri. A. Akdoğanbulut İnsan \& A. Yavuz Akengin (Ed.), Cumhuriyet'in Kuruluşundan Günümüze Eğitimde Kademeler Arası Geçiş ve Yeni Modeller Uluslararası Kongresi (ss. 603-618) içinde. Atatürk Kültür, Dil ve Tarih Yüksek Kurumu.

Bölükbaş, S., \& Gür, B. S. (2020). Tracking and inequality: The results from Turkey. International Journal of Educational Development, 78. DOi:org/10.1016/j.ijedudev.2020.102262 
GÜR, ÖZTÜRK, ÖZER \& SUNA - Çukurova Üniversitesi Eğitim Fakültesi Dergisi, 50(2), 2021, 1437-1463

Buluç, B., Çelik, Ö., \& Uzun, E. B. (2014). Temel Eğitimden Ortaöğretime Geçiş (TEOG) sisteminin öğretmen görüşlerine göre değerlendirilmesi. A. Akdoğanbulut İnsan \& A. Yavuz Akengin (Ed.), Cumhuriyet'in Kuruluşundan Günümüze Eğitimde Kademeler Arası Geçiş ve Yeni Modeller Uluslararası Kongresi (ss. 267-289) içinde. Atatürk Kültür, Dil ve Tarih Yüksek Kurumu.

Cerna, L. (2017). The nature of policy change and implementation: A review of different theoretical approaches. Organisation for Economic Co-operation and Development.

Corrales, J. (1999). The politics of education reform: Bolstering the supply and demand; overcoming institutional blocks. The World Bank. https://eric.ed.gov/?id=ED466819

Creswell, J. W. (2010). Research design: Qualitative, quantitative, and mixed methods approaches. California: Sage Publications.

Cuban, L. (2008). Frogs into princes: Writings on school reform. Teachers College Press.

Çelik, Z. (2012). Ortaöğretime geçiş sınav sistemi ve politikaları. 21. Yüzyılda Türkiye'nin Eğitim ve Bilim Politikaları Sempozyumu (10-11 Aralık 2011) (ss. 53-60) içinde. Eğitimciler Birliği Sendikası.

Çelik, Z. (2015). Ortaöğretime ve yükseköğretime geçiş sınavları kıskacında ortaöğretim sistemi. A. Gümüş (Ed.), Türkiye'de eğitim politikaları (ss. 273-296) içinde. Ilem Kitaplığı \& Nobel.

Çelik, Z., Boz, N., Arkan, Z., \& Toklucu, D. K. (2017). TEOG yerleştirme sistemi: Güçlükler ve öneriler. Siyaset, Ekonomi ve Toplum Araştırmaları Vakfı.

Demirbilek, M., \& Levent, A. F. (2019). Kademeler arası geçiş ve sınav sisteminde yapılan değişikliklere ilişkin okul yöneticilerinin görüşleri. Marmara Üniversitesi Atatürk Eğitim Fakültesi Eğitim Bilimleri Dergisi, 50(50), 57-79.

Dinç, E., Dere, İ., \& Koluman, S. (2014). Yaşantısal perspektiften eğitimde kademeler arası geçiş. A. Akdoğanbulut İnsan \& A. Yavuz Akengin (Ed.), Cumhuriyet'in Kuruluşundan Günümüze Eğitimde Kademeler Arası Geçiş ve Yeni Modeller Uluslararası Kongresi (ss. 409-427) içinde. Atatürk Kültür, Dil ve Tarih Yüksek Kurumu.

Dünya Bankası. (2013). Türkiye'de okullarda mükemmeli teşvik etmek. World Bank.

Eğitimi Araştırma ve Geliştirme Dairesi Başkanlı̆̆ı. (2010). Seviye Belirleme Sınavının değerlendirilmesi. Milli Eğitim Bakanlı̆̆ı.

Fullan, M. (2000). The three stories of education reform. Phi Delta Kappan, 81(8), 581-584.

Fullan, M. (2009). Large-scale reform comes of age. Journal of Educational Change, 10(2), 101-113. https://doi.org/10.1007/s10833-009-9108-z

Gür, B. S. (2014). Eğitimle imtihan (2004-2013). Siyaset, Ekonomi ve Toplum Araştırmaları Vakfı.

Gür, B. S., \& Çelik, Z. (2009). Türkiye'de millî eğitim sistemi: Yapısal sorunlar ve öneriler (Rapor Sy 1). Siyaset, Ekonomi ve Toplum Araştırmaları Vakfı.

Gür, B. S., Çelik, Z., \& Coşkun, i. (2013). Türkiye'de ortaöğretimin geleceği: Hiyerarşi mi, eşitlik mi? (Analiz Sy 69). Siyaset, Ekonomi ve Toplum Araştırmaları Vakfı.

Gür, B. S., Çelik, Z., \& Yurdakul, S. (2016). Beşinci sınıfın yabancı dil dersi ağırlıklı hale getirilmesi: Zorluklar, riskler ve alternatifler (Odak Analiz Sy 1). Eğitim-Bir-Sen Stratejik Araştırmalar Merkezi.

Gürses, G., \& Helvacı, M. A. (2011). Öğretmenlerin okullarda değişime karşı direnme nedenleri. Uluslararası Insan Bilimleri Dergisi, 8(1), 1540-1563.

Hanushek, E.A., \& Woessmann, L. (2006). Does educational tracking affect performance and inequality? Differences-in-differences evidence across countries. The Economic Journal, 116, 63-76.

Kalkınma Bakanlığı. (2014). Eğitim sisteminin kalitesinin artırılması özel intisas komisyonu raporu. Kalkınma Bakanlı̆̆ı. 
GÜR, ÖZTÜRK, ÖZER \& SUNA - Çukurova Üniversitesi Eğitim Fakültesi Dergisi, 50(2), 2021, 1437-1463

Karaağaç Cingöz, Z., \& Gür, B. S. (2020). Ekonomik, sosyal ve kültürel statünün akademik başarıya etkisi: PISA 2015 ve TEOG 2017 sonuçlarının karşılaştırması. İnsan ve Toplum, 10(4), 247-288. DOi:/10.12658/M0563

Karakaya, F., Bulut, A. E., \& Yılmaz, M. (2020). Fen lisesi öğretmenlerinin TEOG ve LGS sistemlerine yönelik görüşleri. Ihlara Eğitim Araştırmaları Dergisi, 5(1), 116-126.

Konan, N., Bozanoğlu, B., \& Çetin, R. B. (2019). Milli Eğitim Bakanlığı teftiş politikalarına ilişkin okul yöneticileri ve öğretmen görüşleri. Eğitimde Nitel Araştırmalar Dergisi, 7(4), 1449-1474.

Küçüker, E. (2017). Türkiye'de kademeler arası geçiş ve öğrenci akışının gelişimi. Ankara Üniversitesi Eğitim Bilimleri Fakültesi Dergisi, 50(1), 43-97.

MEB. (2009). Milî eğitim bakanlığı 2010-2014 stratejik planı. MEB.

MEB (2018). 2018 Liselere Geçiş Sistemi (LGS): Merkezi sınavla yerleşen öğrencilerin performansı. Eğitim Analiz ve Değerlendirme Raporları Serisi: 3. Ankara: MEB

MEB. (2019a). Millî Eğitim Bakanlığı 2019-2023 stratejik planı. Ankara: MEB.

MEB. (2019b). 2019 Ortaöğretim kurumlarına ilişkin merkezi sınav. Eğitim Analiz ve Değerlendirme Raporları Serisi: 7. Ankara: MEB.

MEB. (2020). 2020 Ortaöğretim kurumlarına ilişkin merkezi sınav. Eğitim Analiz ve Değerlendirme Raporları Serisi:12. Ankara: MEB.

OECD. (2010). PISA 2009 results: Overcoming social background-Equity in learning opportunitiesand outcomes vol II. Organisation for Economic Co-operation and Development.

OECD. (2018). Education at a glance 2018: OECD indicators. Organisation for Economic Co-operation and Development.

OECD. (2019a). Country note: Turkey (Results from PISA 2018). Organisation for Economic Co-operation and Development.

OECD. (2019b). PISA 2018 results: Volume I. Paris: Organisation for Economic Co-operation and Development.

Ozturk, A., \& Tumen, S. (2018). Education and labor market consequences of student protests in late 1970s and the subsequent military coup in Turkey. IZA Discussion Paper No. 11733. http://bit.ly/2WN8LAJ

Özdal, F. (2019). Merkezi yerleştirme sınav sistemine ilişkin öğretmen ve öğrenci görüşlerinin değerlendirilmesi. Mukaddime, 10(2), 688-707.

Özer, M. (2020a). Mesleki eğitimde paradigma değişimi: Türkiye'nin mesleki eğitim ile imtihanı. İstanbul: Maltepe Üniversitesi Yayınları.

Özer, M (2020b). What PISA tells us about performance of education systems? Bartın University Journal of Faculty of Education, 9(2), 217-228.

Özer, M., \& Perc, M. (2020). Dreams and realities of school tracking and vocational education. Palgrave Communications, 6(1). DOi:/10.1057/s41599-020-0409-4

Özkan, E., \& Karataş, ì. H. (2016). Ortaöğretime geçiş sisteminde yapılan değişikliklere ilişkin öğrenci görüşlerinin analizi. Eğitim ve Öğretim Araştırmaları Dergisi, 5(1), 214-223.

Pellizzari, M., \& Billari, F. (2011). The younger, the better? Age related differences in academic performance at university. Journal of Population Economics 25(2), 697-739.

Salkind, N. J. (2010). Encyclopedia of research design. California: SAGE Publications.

Suna, H. E., Tanberkan, H., \& Özer, M. (2020). Changes in literacy students in Turkey by years and school types: Performance of students in PISA applications. Journal of Measurement and Evaluation in Education and Psychology, 11(1), 76-97. 
GÜR, ÖZTÜRK, ÖZER \& SUNA - Çukurova Üniversitesi Eğitim Fakültesi Dergisi, 50(2), 2021, 1437-1463

Suna, H. E., Tanberkan, H., Gür, B.S., Perc, M. \& Özer, M. (2020a). Socioeconomic status and school type as predictors of academic achievement. Journal of Economy Culture and Society, 61(1), 41-64.

Suna, H. E., Gür, B. S., Gelbal, S., \& Özer, M. (2020b). Fen lisesi öğrencilerinin sosyoekonomik arkaplanı ve yükseköğretime geçişteki tercihleri. Yükseköğretim Dergisi, doi:10.2399/yod.20.734921.

Şahin, S., Uz Baş, A., Sucuoğlu, H., \& Şahin Fırat, N. (2012). İlköğretim okulu öğrenci ile öğretmenlerinin ortaöğretime geçiş sistemine ilişkin görüşleri. International Journal of Human Sciences, 9(2), 847-878.

TED (2010). Ortaöğretime ve yükseköğretime geçiş sistemi. Ankara: Türk Eğitim Derneği.

Tyack, D. B., \& Cuban, L. (1997). Tinkering toward utopia: A century of public school reform (Revised edition). Harvard University Press.

Viennet, R., \& Pont, B. (2017). Education policy implementation: A literature review and proposed framework. OECD Education Working Papers. https://doi.org/10.1787/fc467a64-en

Waldow, F. (2009). What PISA Did and Did Not Do: Germany after the 'PISA-shock': European Educational Research Journal. https://doi.org/10.2304/eerj.2009.8.3.476

World Bank. (2005). Turkey: Education sector study (Sy 32450-TU). World Bank.

Wurzburg, G. (2010). Making reform happen in education. Making reform happen: Lessons from OECD countries (ss. 159-181) içinde. Organisation for Economic Co-operation and Development. https://www.oecd-ilibrary.org/economics/making-reform-happen/making-reform-happen-ineducation_9789264086296-7-en

Yavuz, M., \& Derinbay, D. (2014). Türkiye'de ortaöğretime geçiş için bir model önerisi. A. Akdoğanbulut Insan \& A. Yavuz Akengin (Ed.), Cumhuriyet'in Kuruluşundan Günümüze Eğitimde Kademeler Arası Geçiş ve Yeni Modeller Uluslararası Kongresi (ss. 181-199) içinde. Atatürk Kültür, Dil ve Tarih Yüksek Kurumu.

Zayimoğlu Öztürk, F. (2014). Orta öğretime geçişte merkezî sınav yapmayan ülke örnekleri ve Türkiye modeli. A. Akdoğanbulut İnsan \& A. Yavuz Akengin (Ed.), Cumhuriyet'in Kuruluşundan Günümüze Eğitimde Kademeler Arası Geçiş ve Yeni Modeller Uluslararası Kongresi (ss. 217-233) içinde. Atatürk Kültür, Dil ve Tarih Yüksek Kurumu. 